\section{Kastamonu Eğitim Dergisi Kastamonu Education Journal}

Mart 2019 Cilt:27 Sayı:2

kefdergi.kastamonu.edu.tr
Başvuru Tarihi/Received: 19.02.2018

Kabul Tarihi/Accepted: 19.06.2018

DOI: $10.24106 /$ kefdergi. 2719

\title{
Türkiye'de İlköğretimde Görsel Sanatlar ile ilgili Yapılan Lisansüstü Tezlerin Eğilimleri
}

\section{Trends in Masters' Theses on Visual Arts in Turkish Primary Education'}

Öz

\author{
Ayşegül OĞUZ NAMDAR², Vildan ÖNDER ${ }^{3}$
}

Bu araştırmanın amacı, Türkiye'de ilköğretim düzeyinde görsel sanatlar ile ilgili yapılan lisansüstü tezlerin içerik analizini yaparak eğilimlerini belirmektir. Bu amaçla, YÖK ulusal tez veri merkezinden ilköğretim ve görsel sanatlar ile ilgili anahtar kelimeler gelişmiş tarama yapılarak 84 tane tez nitel araştrma kapsamında içerik analizi ile analiz edilmiştir. Bu araştırma, erişme izin durumundan "izinli" tezler seçilerek, geçmişten 2016 yılın sonuna kadar yapılan tezler ile sınırlandırılmıştır. Araştırmada tezler danışman unvanı, tarih, üniversite, bölüm, düzey, yöntem, grup seçimi, çalışma grubu düzeyi, çalışma grubu büyüklüğü, veri toplama araçları, öneriler, anahtar kelimeler, araştırmacı cinsiyeti, yerli ve yabancı kaynakça sayısı bakımından incelenmiştir. Bulgular frekans ve kod tabloları ile sunulmuştur. Araştırma sonuçlarına bakıldı̆ıında Türkiye'de ilköğretim düzeyinde görsel sanatlarla ilgili yapılan lisansüstü tez yazarlarının büyük çoğunluğunun kadın olduğu, tezlerin danışmanlarının büyük çoğunluğunun Yrd. Doç. Dr. Unvanına sahip olduğu, tez basım tarihinin yıllara göre dağılımına bakıldığında en fazla tezin 2011 yılında yapıldığı, en fazla tezin Gazi Üniversitesinde yazıldığı, en fazla tezin resim-iş öğretmenliği bölümünde yazıldığı, en fazla tezin yüksek lisans düzeyinde olduğu görülmüştür. Tezlerin yöntemine bakıldığında büyük oranda nitel tezlere ağılık verildiği, çalışma grubu olarak en çok ilköğretim öğrencileriyle çalışıldığı, veri analizi yöntemlerinden nitel araştırmalarda en çok içerik analizi ve doküman analizi yapıldığı; nicel araştırmalarda SPSS kullanıldığı görülmüştür. Tezler öneriler bakımından incelendiğinde, hizmet içi eğitim ve seminerlerin verilebileceği, sanat eğitimi ortamlarının gerekli materyallerle donatılması gerektiği, görsel sanatlar ders süresinin artırılması gerektiği, müzelerle işbirliği yapılması gerektiği en sık tekrar edilen öneriler arasında yer almaktadır.

Anahtar Kelimeler: İçerik analizi, lisansüstü tezleri, ilköğretim, görsel sanatlar

\section{Abstract}

The purpose of this study is to identify the trends in master's theses on visual arts conducted in Turkish primary education. We used different combination of keywords regarding visual arts and primary education and identified 84 master's theses. Utilizing content analysis, we identified the title of the advisor, date, university, department, level, methods, sampling method, grade level, sample size, data collection, implications, keywords, gender of the researcher, the number of Turkish and English sources were identified. Findings were given in frequency and coding tables. The results indicated that most master's thesis on visual arts conducted in Turkey writers were female, the advisor of the theses were mostly assistant professor, thesis were mostly published in 2011, most theses were published in Gazi University, most thesis were published in arts education departments, most theses were in master's degree. Most studies utilized qualitative analysis and conducted with primary school students. Data analysis techniques included content analysis and documents analysis. Examining the implications of the thesis results showed that professional development courses could be given, art education environments should be equipped with proper materials, duration of visual arts courses should be increased, and collaboration with museums should be established.

Keywords: Content analysis, graduate thesis, primary education, visual arts

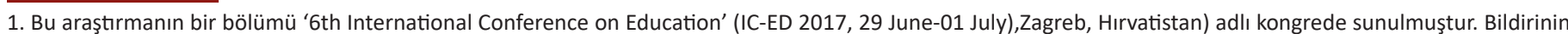
özet metni yayınlanmıştır.

2. Recep Tayyip Erdoğan Üniversitesi, Eğitim Fakültesi, Rize, Türkiye; https://orcid.org/0000-0002-6853-8507

3. Recep Tayyip Erdoğan Üniversitesi, Eğitim Fakültesi, Rize, Türkiye; https://orcid.org/0000-0001-6228-3913

Atıf / Citation: Oğuz Namdar, A., \& Önder, V. (2019). Türkiye'de ilköğretimde görsel sanatlar ile ilgili yapılan lisansüstü tezlerin eğilimleri. Kastamonu Education Journal, 27(2), 767-784. doi:10.24106/kefdergi.2719 


\section{Extended Summary}

Every scientific and artistic work produced in the field of art education contributes to the field. The existence and the increase of the theses produced in the arts education at the graduate and doctoral levels in universities is one of the situations which shows the necessity of this field and the field which should be emphasized. The existence of these studies is also creating new research grounds. Determination of trends of researches, trends of theses based on some variables, determination of the need in the field from the results obtained based on the researches conducted and from their suggestions, is of great importance in terms of forming a basis for new studies to be made. In each research, suggestions given by the results of their research lead to the lack and the absence in the field. It seems that it is important to determine the tendencies of researches if every work produced in visual arts in primary education can be filled with a labor product, a gap in the field and can shed light on new researches, and new applications can be made from the suggestions. It can be said that master and doctoral dissertations produced for the development of studies related to the visual arts have a great role. Examining the theses produced in detail through thesis classification form will give detailed information about the tendencies in the field. In this respect, it is important that such studies are carried out and maintained.

The purpose of this study is to conduct a content analysis of graduate thesis written about the visual arts appear at primary level in Turkey and determine the tendencies. For this purpose, the key words related to primary education and visual arts from the national thesis data center of HEC were screened and 84 thesis analyzed by content analysis within the scope of qualitative research. A total of 81 theses have been downloaded on May 2, 2017 by choosing the keywords 'visual arts' and 'primary education' from the Advanced Search option in the HEC National Thesis Data Center, and 'open access' from the permission status option. On May 25, 2017, a total of 3 theses were downloaded on the same page by choosing the 'visual arts' and 'primary school' keywords and open access option on the same page. $81+3=84$ open access theses were examined within the scope of this research. This research was limited to theses written from the past to the end of 2016, by selecting "open access" theses from the grant of access.

In the research, the theses were examined in terms of advisor academic title, date, university, department, level, method, group selection, study group level, study group size, data collection tools, data analysis, suggestions, keywords, researcher gender and number of domestic and foreign reference bibliography. The findings are presented with frequency and code tables. In order to ensure the reliability of the code obtained, the data was coded by two independent coders and code reliability is provided by looking at the consistency between the codes found by the two researchers.

According to the research results theses completed about the visual arts at the primary level in Turkey the majority of the writers were women, thesis advisors were mostly associate professors, the most theses were written in 2011, most of the thesis is written in Gazi University, most of the thesis is written in the department of painting-work teacher education, and most of the thesis is in graduate level. When the method of the theses is examined, it is seen that most of the theses employed qualitative research, the study group was mostly primary students, in qualitative research data analysis methods content analysis and document analysis are most performed, SPSS was mostly used in quantitative research. When the theses are examined in terms of implications, one of the most frequently repeated suggestions were in-service training and seminars should be given, art education environments should be equipped with necessary materials, visual arts course duration should be increased and collaboration should be done.

Based on the results of this research it is suggested that research on visual arts at the primary education level should be conducted. It is expected that in the primary education in which interest, attitude and awareness towards the visual art will be formed and shaped, the tendency in the different levels, study groups and variables to be used together with the qualitative, quantitative or both research methods to be done about the visual arts is expected to increase. Particularly, it is thought that the experimental applications which will be done in the primary education related to the visual arts will make a great contribution to the literature and to shaping students' attitudes towards the arts. It may be advisable to carry out research that could create a solution to the difficulties encountered in the implementation of visual arts courses in primary education. 


\section{Giriş}

Bilimsel araştırmalar her zaman birbirine benzer yöntemlerle ilerlemeyebilir. Bilimsel araştırmaların değişen paradigmalar, değişen öğretim programları gibi değişkenlerin de etkisiyle kendini değiştireceği, dönüştüreceği düşünülürse zaman zaman eğilimlerinin de değişebileceği görülmektedir. Bilimsel araştrrmaların zaman zaman hangi yöne eğilim gösterdiğinin belirlenmesi, var olan araştrrma yöntemlerinin, o alanla ilgili eğilimlerin ne yönde olduğunun belirlenmesi büyük önem taşımaktadır. Söz gelimi, değişen paradigmalara bağıı olarak yapılan araştırmaların yöntemleri de değişebilmektedir. 'Türkiye'de görsel sanatlar öğretimi konusunda yapılan araştırmaların uzun bir süre nicel araştrrmalara dayalı olarak yapıldığı bir gerçektir. Oysa sanatın doğası, bu konuda yapılacak araştırmaların nitel analizlere de dayalı yapılmasını gerektirmektedir. Sanat eğitimi disiplininin sosyo-kültürel özelliklerinden dolayı nitel araştırma basamakları izlenerek incelenmesi daha uygun görülmektedir' (Alakuş, 2009: 57). Geçmişten günümüze eğitim-öğretim ile ilgili de pek çok gelişim, değişim ve dönüşüm olmuştur. Bu gelişim, değişim ve dönüşüm, eğitim ile ilgili araştirmalara da yansımaktadır. Eğitimde yer alan en önemli alanlardan bir tanesi de sanat eğitimidir. 'Sanat eğitimi tamamen bilimsel bir disiplindir ve bilimsel araştırmalarla oluşturulmuştur' (Özsoy, 2016: 156).

Sanatın bugüne kadar pek çok tanımı yapılmıştır. Artut (2006: 19) sanat "insan ile doğadaki nesnel gerçekler arasındaki estetik ilişkinin dışavurumu" olarak tanımlamaktadır. Read’a göre (1984) basit anlamıyla sanat genellikle "plastik" ya da "görsel" kavramlarıyla ilişkilendirilir, ancak edebiyat ve müzik kavramlarını da içermektedir. Pasin'e göre (2004: 13) sanat, "insanla doğadaki nesnel gerçekler arasındaki estetik ilişkidir, görmeyi öğrenmedir". Sanat dünyayı anlamak ve değiştirmek olarak algılandığında kişi çevresine, içinde yaşadığı topluma eleştirel bir gözle bakar, güzelliklerden mutlu olur, çirkinlikleri, olumsuzlukları değiştirme çabası içine girer (Kırışoğlu, 2009). Bu da kişinin sanata ilişkin aldığı eğitimle olanaklı olabilir. "Sanat hem öğrenme sürecinin hem de gelişim sürecinin etkin bir yardımcısı olabilir. Çünkü sanat, duygu ve düşünce arasındaki karşılıklı ve iç içe geçmiş bağlantıyı vurgular" (San, 1979: 1). "Bir duygu ve akıl varlığı olarak insanın sadece akıl yönünün geliştirilmesi onun tam insan olabilmesi için yeterli değildir; duygu değerlerine de gereksinimi vardır" (Gençaydın, 2002: 29). 20. Yüzyılın başından bu yana sanat eğitimi kavramı, kaplamsal ve genel anlamda, güzel sanatların tüm alanlarını ve biçimlerini içine alan, okul içi ve okul dışı yaratıcı sanatsal eğitimi tanımlamaktadır (San, 1983). "Çağdaş insan kimliği sanatsal yetişmeyi de içermektedir" (Öztürk, 1994: 4). Sanat eğitimi hangi öğretim-eğitim kademesinde olursa olsun, ülkenin toplumun genel kültür, sanat ve eğitim birikimi ile doğrudan ilişkilidir (Pekmezci, 1997). "Sanat eğitiminin baş amaçlarından biri, görmeyi, işitmeyi, dokunmayı, tat almayı öğretmektir. Çevresini hakkıyla algılayıp onu biçimlendirmeye yönelmek için bu, gerekli ilk koşuldur" (San, 2008: 25). Alakuş ve Mercin'e göre (2009) sanat eğitimi, bireyin kendisini ifade etmesinin, estetik değer yargılarının oluşmasının, başkalarını anlayabilmesinin, sanata ve sanatçıya değer vermesinin, yaratıcı düşüncesini teşvik etmesinin, problemlere karşı özgün çözüm önerileri geliştirebilmesinin ve diğer disiplinlerle iş birliği sağlayarak sanat yoluyla öğrenebilmesinin bir gereğidir. Alan yazından da görüldüğü gibi, sanat eğitiminin pek çok amacı ve işlevi bulunmaktadır.

Türkiye'de sanat eğitimi bakımından bazı gelişmeler söz konusu olmaktadır. İlköğretimde, temel eğitim düzeyinde sanat eğitimi dersleri 'resim-iş' dersi olarak programda yer almaktaydı, ancak 2005 yılındaki öğretim programları değişikliği ile birlikte resim-iş dersi 'görsel sanatlar' adını almıştır. Özsoy'a göre (2016) güzel sanatlar eğitiminin önemli bir dalı olan görsel sanatlar eğitiminde son yıllarda kayda değer geliş̧meler olmaktadır. Bunlar ilk ve ortaöğretimde 'Resim-iş̧ Dersi' adının 'Görsel Sanatlar Dersi' olarak değiştirilmesi, ilk ve ortaöğretim görsel sanatlar ders programlarının 'yapılandırmacı' anlayışa göre düzenlenmesi, öğretmen yetiştiren Resim-iş̧ Eğitimi Bölümlerinin yeniden yapılandırılması, Güzel Sanatlar Fakülteleri mezunlarına yönelik Resim Öğretmenliği Tezsiz Yüksek Lisans Programlarının açılması, görsel sanatlar eğitiminde yüksek lisans ve doktora eğitimindeki hızlı artı̧̧ örgün eğitimdeki önemli gelişmeler olarak karşımıza çıkmaktadır. 'Kişinin yetişmesinde sanatın önemi, gelişmişülkelerde çok iyi bilinmektedir. Bu nedenle örgün ve yaygın eğitimde sanata yer verilmiştir. Sanat eğitiminde 'yaratıcılık' vurgulanır. Bu yolda yapıcılığa ve üretkenliğe yönlendirilir. Ülkemizde de bu gerçek daha yeni anlaşılmaya başlandığı için son zamanlarda eğitim sistemimizde sanat derslerine yer verilmektedir' (Tezcan, 2011: 141). Okul öncesinden başlayarak eğitim-öğretimin her kademesinde yer alması gereken görsel sanatlar dersleri ya da genel anlamda sanat eğitimi dersleri, alanında uzman öğretmenler tarafindan büyük bir titizlikle verilmesi gerekir. Çünkü 'günümüz eğitim sisteminden beklenilen, sadece belirli bilgi ve becerilerin öğrencilere kazandırılması değildir. Daha önemlisi bireyin bunlardan değişik sentezlerle farklı fikirler, ürünler ortaya çıkarabilme yeteneğinin geliştirilmesi ve kazandığı bu davranışları gerektiği zaman ve yerde uygulayabilmesidir. Sanatta yaratıcılık kavramını açıklayan bu davranış biçimiyle dünyayı algılayabilmek ve gerekli alışkanlıkları edinebilmenin bir yolu da sanattan geçmektedir (Gökay, 2009).

Değişik kaynaklarda bulunan eserler incelendiğinde dünyada ne kadar çok değişik anlatımların bulunduğunu ve bu anlatımların tekrarlanmadan her defasında yeni ve orijinal fikirlerle devam ettiğini görmek mümkündür (Gökay, 2010). 
Sanat eğitimi alanında üretilen her bilimsel ve sanatsal çalışma, alana katkı sağlamaktadır. Üniversitelerde yüksek lisans ve doktora düzeyinde sanat eğitimine ilişkin üretilen tezlerin varlığı ve artışı da bu alanın gerekliliğini ve üzerinde durulması gereken bir alan olduğunu gösteren durumlardan bir tanesidir. Bu çalışmaların varlığı da, beraberinde yeni araştırmalara zemin oluşturmaktadır. Alan yazında pek çok alana yönelik araştırmaların içerik analizinin yapıldığı ve sınırlandırılmış bir alan ile ilgili eğilimlerin belirlendiği görülmektedir. Bu araştırmalardan bazıları Wassink ve Sadi (2016), Çalık, Ünal, Coştu \& Karataş (2008); Fışkın ve Nas (2013); Bağ ve Çalık (2017); Aydın ve Uysal (2004); Chang \& Hsieh (1997); Juodaitytė \& Kazlauskienė (2008); Williams ve Buboltz (1999); Cavas ve diğerleri (2012), Hüseyinbaş ve diğerleri (2018); Yalçın ve diğerleri (2009); Sözbilir ve diğerleri (2012); Doğru ve diğerleri (2012); Bağ, Kara \& Uşak (2002); Kayhan \& Koca (2004); Cavitt (2006); Çakmakçı (2006); Altınkurt (2007); Guo ve Sheffield (2008); Şara ve diğerleri (2016); Sert ve diğerleri (2012); Oruç ve diğerleri (2008); De Jong (2007) tarafindan hazırlanan, bir alan ile sınırlandırılmış araştırmaların içerik analizinin yapıldığı çalışmalardır.

Yapılan araştırmaların, üretilen tezlerin bazı değişkenlere göre eğilimlerinin belirlenmesi, yapılan araştırmalardan elde edilen sonuçlardan ve önerilerden yola çıkarak alandaki gereksinimin de belirlenmesi, yapılacak yeni çalışmalara temel oluşturması bakımından büyük önem taşımaktadır. Her araştırmada, kendi araştırma sonuçlarından yola çıkarak önerilen öneriler alandaki eksikliğe ve boşluğa yol göstermektedir. îlköğretimde görsel sanatlar ile ilgili üretilen her çalışmanın bir emek ürünü, alanda bir boşluğu doldurabileceği ve yeni araştırmalara ışık tutabileceği ve önerilerden yola çıkarak yeni uygulamaların yapılabileceği düşünülürse araştırmalarının eğilimlerinin belirlenmesinin önem taşıdığı görülmektedir. Görsel sanatlar alanında üretilen yüksek lisans ve doktora tezleri de, alanın gelişimine katkı sağlayabilir. Üretilen tezlerin ayrıntılı biçimde tez sınıflandırma formu aracılığıyla incelenmesi alandaki gidişat hakkında ayrıntılı bilgi verecektir. Bu araştırma, araştırmacılara alan yazındaki güncel çalışmaları ve eğilimleri daha rahat takip etme olanağı sunması bakımından önemlidir. Bu bakımdan bu tür çalışmaların yapılması ve devamlılığı önem taşımaktadır.

\section{Yöntem}

\section{Veri Toplama Araçları}

Bu araştırmanın amacı, Türkiye'de ilköğretim düzeyinde görsel sanatlar ile ilgili yapılan lisansüstü tezlerin içerik analizini yaparak eğilimlerini belirmektir. Bu amaçla, YÖK ulusal tez veri merkezinden ilköğretim ve görsel sanatlar ile ilgili anahtar kelimeler gelişmiş tarama yapılarak 84 tane tez nitel araştırma kapsamında içerik analizi ile analiz edilmiştir. Tezlerin elde edilişinde, YÖK Ulusal Tez Veri Merkezinden Gelişmiş arama seçeneğinden anahtar kelimeler 'görsel sanatlar' ve 'ilköğretim' olarak, izin durumu seçeneğinden 'izinli' seçeneği seçilerek kayıtta çıkan toplam 81 tez 2 Mayıs 2017 tarihinde indirilmiştir. 25 Mayıs 2017 tarihinde aynı sayfa üzerinden gelişmiş aramada 'görsel sanatlar' ve 'ilkokul' anahtar kelimeleri ve izinli seçeneği seçilerek kayıtta görülen toplam 3 tez indirilmiştir. İzinli olarak elde edilen $81+3=$ 84 tez, bu araştırma kapsamında incelenmiştir. Bu araştırma, erişme izin durumundan “izinli” tezler seçilerek, geçmişten 2016 yılın sonuna kadar yapılan tezler ile sınırlandırılmıştır. Bu araştırma kapsamında incelenen tezlere EK-1'de yer verilmiştir.

Araştırmanın geçerlik ve güvenirliğini sağlamak için bazı önlemler alınmıştır. Kodlamalar, daha önceden belirlenen başlıklara göre yapılmıştır. Kodlamalar yaklaşık 6 hafta sürmüştür. Kodların yeniden kontrolünün sağlanabilmesi için incelenen her bir teze numara verilmiştir. Kod güvenirliğini sağlamak amacıyla iki araştırmacı tarafindan bağımsız kodlama yapılmıştır. Kodlayıcı güvenirliği, Miles ve Huberman'ın (1994) görüş birliği ve görüş ayrılığını kapsayan Güvenirlik = Görüş birliği / ( Görüş Birliği + Görüş Ayrılığı) ) x 100 formülüyle hesaplanmış ve 0.94 olarak belirlenmiştir. Araştırmada hiç bir verinin kaybedilmemesi için iki araştırmacı tarafindan titizlikle kodlama yapılmıştır.

\section{Veri Analizi}

Araştırmada tezler danışman unvanı, tarih, üniversite, bölüm, düzey, yöntem, grup seçimi, çalışma grubu düzeyi, çalışma grubu büyüklüğü, veri toplama araçları, veri analizi, öneriler, anahtar kelimeler, araştırmacı cinsiyeti, yerli ve yabancı kaynakça sayısı bakımından incelenmiştir. Bulgular frekans ve kod tabloları ile sunulmuştur. Elde edilen kod güvenirliğini sağlamak amacıyla, araştırma verileri iki bağımsız kodlayıcı tarafindan kodlanmış, iki araştırmacının bulduğu kodlar arasındaki tutarlığa bakılarak kod güvenirliği sağlanmıştır.

\section{Bulgular}

Bu araştırma kapsamında incelenen tezler, içerik analizi ile analiz edilerek bu bölümde sunulmuştur. Verilerin gösterimi kod ve frekans tabloları hazırlanarak yapılmıştır. 
Tablo 1. Tezlerin danışman unvanına göre dağılımı

\begin{tabular}{llc}
\hline \multirow{3}{*}{ Unvan } & Kod & Frekans \\
\cline { 2 - 3 } & Yrd. Doç. Dr. & 45 \\
& Prof. Dr. & 31 \\
& Doç. Dr. & 8 \\
\hline
\end{tabular}

Tablo 1'de tezlerin danışman unvanına göre dağılımına bakıldığında, incelenen tezler içerisinde danışmanlık yapan öğretim üyelerinden 45 Yrd. Doç. Dr., 31 Prof. Dr. ve 8 Doç. Dr. olduğu görülmüştür. Üniversitelerde görev yapan öğretim üyelerinden büyük çoğunluğunun Yrd. Doç. Dr. unvanında olduğu düşünülürse, bu bulgunun beklenen bir bulgu olduğu söylenebilir. İş yükü bakımından hangisinin daha çok çalışmak zorunda olduğu akademik yükümlülüklerle de ilgili olabilir. Sayısal değer olarak bakıldığında en fazla danışman unvanının Yrd. Doç. Dr. olduğu görülmektedir. Prof. Dr. ve Doç. Dr. sayısı arasında ciddi bir farklılık göze çarpmaktadır. Bazı üniversiteler diğerlerine oranla daha köklü eğitim kurumlarındandır, söz gelimi güzel sanatlar eğitimine yön veren kurumlardan olan Gazi Üniversitesi gibi. Bunun gibi üniversitelerde profesör sayısının fazlalığı olağandır.

Tablo 2.Tezlerin basıldığı tarihe göre dağılımı

\begin{tabular}{ccc}
\hline \multirow{1}{*}{ Kod } & Frekans \\
\cline { 2 - 2 } Tarih & 18 \\
2011 & 17 \\
2010 & 13 \\
2009 & 7 \\
2012 & 7 \\
& 2008 & 5 \\
2007 & 5 \\
2013 & 4 \\
2014 & 4 \\
2006 & 3 \\
2016 & 1 \\
\hline
\end{tabular}

Tablo 2'de tezlerin basıldığı tarihe göre dağııımına bakıldığında konu ile ilgili en fazla tezin 2011 yılında, onu takiben 2010 ve 2009 yılında yapıldığı görülmektedir. 2005 yıından bugüne konu ile ilgili tez yazımında bir artı̧̧ olduğu görülmektedir. Bu da ilköğretim düzeyinde görsel sanatlar eğitimine verilen, verilmesi gereken önemin arttğına ilişkin bir ipucu olabilir. Diğer yıllara oranla, 2011 yılında üretilen tez sayısında bir yoğunluk olduğu göze çarpmaktadır. Tezi yazan öğrencilerle de ilgili olabilir. Görsel sanatlar öğretim programlarının değişikliği de etki etmiş olabilir, ancak 2005 yılında resim-iş dersi öğretim programı değişmiş, buna rağmen ilgili anahtar kelimelerle arama yapılarak bulunan tez sayısı oldukça düşüktür. Tablo 2'de yıllara göre dağııımda bir dalgalanma olduğu, istikrarlı bir artı̧ olmadığı görülmektedir. 2005 ve 2011 yılları arasında radikal bir farklıık olmasına rağmen, tablonun genelinde yıllar arası değişimin de çok radikal olmadığı söylenebilir. 
Tablo 3. Tezlerin yazıldığı üniversiteye göre dağılımı

\begin{tabular}{llc}
\hline & Kod & Frekans \\
\cline { 2 - 3 } & Gazi Üniversitesi & 38 \\
Marmara Üniversitesi & 12 \\
Anadolu Üniversitesi & 6 \\
Çanakkale 18 Mart Üniversitesi & 6 \\
19 Mayıs Üniversitesi & 6 \\
Selçuk Üniversitesi & 5 \\
Üniversite & 9 Eylül Üniversitesi & 3 \\
& Fırat Üniversitesi & 1 \\
& Inönü Üniversitesi & 1 \\
& Mustafa Kemal Üniversitesi & 1 \\
& Uludağ Üniversitesi & 1 \\
& Karadeniz Teknik Üniversitesi & 1 \\
& Necmettin Erbakan Üniversitesi & 1 \\
& Balıkesir Üniversitesi & 1 \\
& Ankara Üniversitesi & 1 \\
\hline
\end{tabular}

Tablo 3'te tezlerin yazıldığı üniversiteye göre dağılımlarına bakıldığında konu ile ilgili tezlerin en fazla üretildiği üniversitenin Gazi Üniversitesi, onu takiben Marmara Üniversitesi, Anadolu Üniversitesi, Çanakkale 18 Mart Üniversitesi, 19 Mayıs Üniversitesi olduğu görülmektedir. En köklü eğitim kurumlarından biri olan Gazi Üniversitesinin Gazi Eğitim Enstitüsü olarak yıllar öncesi eğitim vermeye başlamış, resim-iş öğretmenliği programıyla günümüzdeki en ünlü sanatçıların yetişmesinde öncü bir kurum olmuştur. Bu bakımdan, ilköğretimde görsel sanatlar ile ilgili olarak en fazla lisansüstü tezin Gazi Üniversitesinde üretilmiş olmasının beklendik olduğu söylenebilir.

Tablo 4. Tezlerin bölümlere göre dağılımı

\begin{tabular}{llc}
\hline & Kod & Frekans \\
\cline { 2 - 3 } & Resim-İş Öğretmenliği & 53 \\
Resim-İş Eğitimi & 11 \\
Güzel Sanatlar Eğitimi & 7 \\
Sınıf Öğretmenliği & 4 \\
\multirow{3}{*}{ Bölüm } & Mesleki Resim Eğitimi & 2 \\
& Resim Öğretmenliği & 2 \\
Mesleki Resim-Iş Eğitimi & 1 \\
Eğitim Bilimleri & 1 \\
Türk-İslam Sanatları Tarihi & 1 \\
Matematik Öğretmenliği & 1 \\
Eğitim Yönetimi ve Denetimi & 1 \\
\hline
\end{tabular}

Tablo 4'te tezlerin bölümlere göre dağılımına bakıldığında ilköğretimde görsel sanatlara ilişkin en çok üretilen tezlerin resim-iş öğretmenliği, resim-iş eğitimi, güzel sanatlar eğitimi ve sınıf öğretmenliği olduğu görülmektedir. 2016 yılına kadar sınıf öğretmenliğinde 4 tane tez üretildiği görülmektedir. Sınıf öğretmenlerinin de sanat eğitimi derslerini verdiği düşünülürse sınıf öğretmenliği ana bilim dalında ve ilgili bölümlerde lisansüstü eğitim almakta olan sınıf öğretmenlerinin de sanata ilişkin farkındalıkları ve sanat eğitimiyle ilgili üretecekleri tezlerin de önemli olduğu söylenebilir. Tez üretilen diğer bölümlere bakıldığında mesleki resim eğitimi, resim öğretmenliği, mesleki resim-iş eğitimi, eğitim bilimleri, Türk-i̇slam sanatları tarihi, matematik öğretmenliği, eğitim yönetimi ve denetimi olduğu görülmektedir. Konu ile ilgili yalnızca resim-iş öğretmenliği değil, diğer bölümlerden de tez üretilmiş olması sevindirici bir bulgudur. Sanatın disiplinler arası bir alan olduğu ve diğer derslerde bir araç olarak etkili biçimde kullanılabileceği düşünülürse bu çeşitliliğin artması gerektiği söylenebilir.

Tablo 5. Tezlerin lisansüstü düzeyine göre dağılımı

\begin{tabular}{llc}
\hline \multirow{3}{*}{ Düzey } & Kod & Frekans \\
\cline { 2 - 3 } & Yüksek Lisans Tezi & 69 \\
& Doktora Tezi & 15 \\
\hline
\end{tabular}


Tablo 5'te tezlerin lisansüstü düzeyine göre dağılıma bakıldığında görsel sanatlarla ilgili yapılan tezlerin 69 tanesinin yüksek lisans, 15 tanesinin de doktora düzeyinde olduğu görülmektedir. Doktora düzeyinde eğitim veren bölümlerin yüksek lisansa oranla daha az olduğu düşünülürse, bu bulgunun da şaşırtıcı olmadığı söylenebilir. Ancak, görsel sanatların ilköğretim düzeyinde üzerinde önemle durulması gereken alanlardan biri olduğu düşünülürse, doktora düzeyinde de üretilen tez sayısında artş olması gerekmektedir. Bu da büyük oranda görsel sanatlar ile ilgili doktora programlarının açılmasına ya da ilköğretim doktora programlarında görsel sanatlar ile ilgili tezlere verilecek olan öneme bağlı olacaktır.

Tablo 6. Tezlerin yöntemine göre dağılımı

\begin{tabular}{llc}
\hline \multirow{3}{*}{ Yöntem } & Kod & Frekans \\
\cline { 2 - 3 } & Nitel & 46 \\
& Nicel & 39 \\
\hline
\end{tabular}

Tablo 6'da ilköğretim düzeyinde görsel sanatlarla ilgili tezlerin yöntemine göre dağılımına bakıldığında toplam 84 tez içerisinden 46 tanesinde nitel, 39 tanesinde ise nicel araştırma yöntemlerinin kullanıldığı görülmüştür. Sanat eğitiminde genelde süreç odaklı ve yorumlamaya dayalı araştırmalara; sanatın doğası gereği nitel araştırmalara daha çok yer verilmektedir. Bu açıdan bakıldığında bu bulgunun da beklenen bir bulgu olduğu söylenebilir. Nitelik ya da nicelik, eğitim çıktılarının neye göre değerlendirildiği ile ilgilidir. Eğitimin büyük oranda hemen her kademesinde genelde sonuç odaklı bir yaklaşım vardır. Söz gelimi, üniversiteye giriş sınavları sonuca odaklı, sınava odaklıdır. Ölçülebilirlik bakımından derecelendirilebilir sonuçlardan ziyade daha özgün değerlendirme biçimlerini kullanması bakımından, sanat ürünlerinin değerlendirilmesinde nitel araştırmanın nicel araştırmalara oranla daha yaygın kullanılmasının beklendik bir bulgu olduğu söylenebilir. Her iki yöntem de görsel sanatlar eğitimini farklı açılardan ele almaktadır, bu bakımdan her iki yönteme de ihtiyaç vardır. Ancak sanat eğitiminin doğasında uygun olması bakımından nitel araştırma yöntemleri daha ön planda tutulmuştur.

\section{Tablo 7. Tezlerde çalışma grubunun seçimi}

\begin{tabular}{llc}
\hline & Kod & Frekans \\
\cline { 2 - 3 } & İlöğretim & 61 \\
& Görsel Sanatlar Öğretmeni & 14 \\
& Sınıf Öğretmeni & 6 \\
Çalışma Grubu Seçimi & Resim Öğretmeni & 3 \\
& Müdür ve Müdür Yardımcıları & 3 \\
& Öğretim Elemanları & 1 \\
& Üniversite öğrencileri & 1 \\
& Veli & 1 \\
\hline
\end{tabular}

Tablo 7'de tezlerde çalışma grubu seçimine bakıldığında, incelenen 84 lisansüstü tez içerisinden 61 tanesinde ilköğretim öğrencileriyle, 14 tanesinde görsel sanatlar öğretmenleriyle, 6 tanesinde sını öğretmenleriyle, 3 tanesinde resim öğretmenleriyle, müdür ve müdür yardımcılarıyla, 1tanesinde öğretim elemanları, üniversite öğrencileri ve velilerle çalışımıştır. Görsel sanatlarla ilgili ilköğretim öğrencileriyle yapılan tezlerin çokluğu sevindiricidir. Bunun yanı sıra, diğer çalışma gruplarıyla çalışmak büyük önem taşımaktadır. Sanata ilişkin farkındalığın oluşması, ilginin artması da büyük oranda sanat eğitimi derslerinin yanı sıra çocuğun çevresinde etkileşimde bulunduğu insanların sanatla ilişkileriyle de doğru orantılı olarak değişebilmektedir. Bu bakımdan görsel sanatlarla ilgili özellikle sınıf öğretmenleriyle yapılan çalışmalar çok değerlidir. Karakter gelişiminin, ilgi ve eğilimlerin oluşmaya başladığı somut işlemler döneminde çocuğun en büyük rol modellerinden biri olan sınıf öğretmenlerinin de yeni üretilecek olan tezlerde çalışma grubu olarak alınması önem taşımaktadır. Sınıf öğretmenlerinin lisans düzeyinde aldığı sanat eğitimi dersleri uygulama yapabilmek için çoğunlukla kuram-uygulama bakımından eksik kalabilmektedir. Çocukların ders kapsamında ya da dışında ürettikleri resimlerin doğru biçimde değerlendirilebilmesi, ürünlerinde hem sanatın ilke ve elemanlarının kullanımının değerlendirilmesi, hem de çocukların resminin psikolojik açıklamaları üzerinde de bilgi sahibi olmaları da önem taşımaktadır. Bu bakımdan sanat eğitimiyle ilgili sınıf öğretmenleriyle yapılacak olan araştırmaların desteklenmesi ve artırılması gerekmektedir. Müdür ve müdür yardımcılarıyla yapılan çalışmaların da, sanata ilişkin okullarda üretilecek sergilerin ya da sanatsal etkinliklerin, sanat galerisi, müze, ören yeri gibi okul dışı öğrenme ortamlarının da kullanılabilmesi için, idari olarak destek gerektirmesi bakımından desteklenmesi ve artırılması gerekmektedir. Sanat eğitiminin okul öncesinden başlayıp devam eden bir süreç olduğu düşünülürse, bir bireyin üniversite düzeyinde de alacağı sanat eğitiminin önemi yadsınamaz. Öğretim elemanlarının da sanat olan tutumu, ilgisi ve etkileşimi önem taşımaktadır. Bu bakımdan öğretim elemanlarıyla yapılan araştırmaların da devamının gelmesi beklenmektedir. Velilerle yapılan araştırmalar da, ders kapsamında alınan sanat eğitimi derslerinin okul dışındaki yansıma- 
larının izlenmesi bakımından önem taşımaktadır.

Tez yazarı, uygulamasını kendi sınıfinda yapıyorsa, öğretmenin hazır ulaşılabilir örneklemle çalışması bakımından ilköğretim öğrencileriyle çalışmasının bu bakımdan beklendik olduğu söylenebilir. Doğrudan yapılmaya çalışılan işin mutfağı gibi olduğu söylenirse, bizzat görsel sanatlar uygulamalarının yapıldığı ortamda çalışmanın yapılması diğerlerine göre daha cazip olabilir. Okullarda genelde görsel sanatlar öğretmeninin sayısı sınıf öğretmenleri sayısından daha azdır. Bu bakımdan görsel sanatlar öğretmenlerine ulaşmak sınıf öğretmenlerine ulaşmaktan daha zaman alıcı olabilir. Tabloda yer alan çalışma gruplarına bakıldığında her bir kodu bir organ, tablonun genelini de bir örgüt olarak düşünebiliriz. Her birinin öğrencinin sanata yönelik farkındalık kazanmasında bir etken olduğu söylenebilir. Öğretim elemanlarıyla yapılan ve yapılacak olan çalışmaların önemli olduğu halde, diğer çalışma gruplarına oranla daha az yapılmasının dikkat çekici olduğu söylenebilir. Öğretim elemanlarının öğretmenleri yetiştirmesi, öğretmenlerin öğrencileri yetiştirmesi göz önüne alınırsa, öğretim elemanlarının bu eğitim sürecinin başlatıcı unsurlarından olduğu görülmektedir. Bu bakımdan öğretim elemanlarıyla yapılacak olan araştırmalar önem taşımaktadır.

Tablo 8. Tezlerin çalışma grubu düzeyi

\begin{tabular}{llc}
\hline & Kod & Frekans \\
\cline { 2 - 3 } 6. Sınıf & 23 \\
& 7. Sınıf & 17 \\
Çalışma Grubu Düzeyi & 8. Sınıf & 15 \\
& 5. Sınıf & 11 \\
& 4. Sınıf & 9 \\
& 3. Sınıf & 5 \\
& 1. Sınıf & 2 \\
& 2. Sınıf & 1 \\
\hline
\end{tabular}

Tablo 8'e bakıldığında ilköğretimde görsel sanatlarla ilgili yapılan lisansüstü tezlerin çalışma grubu düzeyine bakıldığında en sık 6. ve 7.Sınıf öğrencileriyle, en az 1. ve 2. Sınıf düzeyindeki öğrencilerle yapıldığı görülmektedir. Yapılan çoğu araştrrmada da sanat eğitiminin okul öncesinden başlayarak verilmesi gerektiği vurgulanmıştır. Bu açıdan bakıldığında üzerinde daha fazla araştırma yapılması gereken, daha etkin eğitim verilmesi gereken dönemlerden birinin de 7-12 somut işlemler dönemi olduğu, özellikle de daha kritik yaş olduğu söylenebilen 1.ve 2. Sınıf düzeyine yönelik sanat eğitimine ilişkin farklı yöntem ve tekniklerin kullanıldığı deneysel çalışmaların da yapılabileceği söylenebilir.

Çocuğun daha özgün ve üretken olduğu temel eğitimin ilk yıllarında, kendini ifade etmesinde resim önemli bir araç olmasına rağmen, bu yaş grubuna ilişkin görsel sanatlarla ilgili üretilen lisansüstü tez sayısının düşüklüğü dikkat çekicidir. Bir üst öğretime hazırlanma aşamasında çocukların üretkenlikten daha uzaklaştı̆ı̆ı söylenebilir. Konu ile ilgili paylaşım ortamının mümkün olması, sanatsal kavramları (estetik, güzellik vd.) düşünme ve anlama, soyut düşünme becerilerinin gelişmesi bakımından 6.sınıf öğrencilerinin çalışma grubu olarak seçilmesinin de anlamlı olduğu görülmektedir. Ancak, somut işlemler döneminin de çalışma grubu olarak seçileceği tezlerin de üretilmesinin alan yazına büyük katkı sağlayacă̆ı düşünülmektedir.

\section{Tablo 9. Tezlerin çalışma grubu büyüklüğü}

\begin{tabular}{llc}
\hline & Kod & Frekans \\
\cline { 2 - 3 } & $1-50$ & 39 \\
& $51-100$ & 25 \\
& $101-150$ & 8 \\
& $151-200$ & 2 \\
Çalışma Grubu Büyüklüğü & $251-300$ & 2 \\
& $351-400$ & 2 \\
& $401-450$ & 1 \\
& 501 ve üstü & 1 \\
& $301-350$ & 0 \\
& $451-500$ & 0 \\
& $201-250$ & 0 \\
\hline
\end{tabular}

Tablo 9'da tezlerin çalışma grubu büyüklüğüne bakıldığında ilköğretimde görsel sanatlarla ilgili olarak tezlerin büyük bir kısmında (39 tane tezde) çalışma grubu olarak 1-50 arası katılımcı seçildiği, yalnızca 1 tezde 501 ve üstü katılımcı ile çalışıldığı görülmektedir. Bir üst tabloda (Tablo 8'de) tezlerin çalışma grup düzeyinde en fazla çalışma yapılan grubun 6. 
Sınıf öğrencileri olduğu görülmektedir. Bir sınıf mevcudunun da 1-50 arası olabileceği düşünülürse, bu bulgunun da bir üst tablodaki verilerle örtüştüğü söylenebilir.

\section{Tablo 10. Tezlerde kullanılan veri toplama araçları}

\begin{tabular}{lll}
\hline & Kod & Frekans \\
\cline { 2 - 3 } & Anket & 34 \\
& Görüşme & 32 \\
& Yapılandırılmış-yapılandırılmamış form & 30 \\
& Doküman inceleme & 23 \\
& İşitsel ve Görsel araç-gereçler (video kaydı, ses kaydı, fotoğraf, resim, etkileşimli CD) & 17 \\
& Gözlem & 16 \\
Nitel veri toplama araçları & Kişisel bilgi formu & 8 \\
& Değerlendirme Kriterleri & 7 \\
& Resim İnceleme & 4 \\
& Günlük & 3 \\
& Öğrenci gelişim dosyası & 2 \\
& Akran değerlendirme formu & 1 \\
& Çalışma yaprağı & 1 \\
& ÇAGSEY & 1 \\
& Çoklu Zekâ Envanteri & 1 \\
\hline & Tutum Ölçeği & 31 \\
Nicel veri toplama araçları Testi & 16 \\
& Diğer ölçekler & 2 \\
\hline
\end{tabular}

Tablo 10'da ilköğretimde görsel sanatlarla ilgili tezlerde kullanılan veri toplama araçlarına bakıldığında, nitel ve nicel veri toplama araçlarının olduğu görülmektedir. Nitel veri toplama araçları olarak en sık anket, görüşme, yapılandırılmış-yapılandırılmamış form, doküman inceleme, işitsel ve görsel araç-gereçler ve gözlem kullanıldığı görülmektedir. Nicel veri toplama araçlarından tutum ölçeği, başarı testi ile diğer ölçeklerin kullanıldığı görülmektedir.

\section{Tablo 11.Tezlerde araştırma sonuçlarına yönelik öneriler}

\begin{tabular}{|c|c|c|}
\hline \multirow{26}{*}{$\begin{array}{l}\text { Tezlerde araştırma } \\
\text { sonuçlarına yönelik } \\
\text { öneriler }\end{array}$} & Kod & Frekans \\
\hline & 1) Hizmet içi eğitimler ve seminerler verilebilir. & 43 \\
\hline & 2) Sanat öğretimine olanak sağlayan fiziksel donanım -görsel materyal sağlanabilir. & 30 \\
\hline & 3) Görsel sanatlar dersi programı uygulamaları için ders süresi arttırılabilir. & 26 \\
\hline & 4) Müzelerle işbirliği yapılabilir. & 24 \\
\hline & 5) GSD müfredat programı geliştirilebilir, güncellenebilir. & 20 \\
\hline & 6) Görsel sanatlar dersi işlenişinde öğrencilerin bireysel özelliklerine (farklılıklar) dikkat edilebilir. & 19 \\
\hline & 7) Görsel sanatlarda öğretim teknolojileri ve materyal tasarımı geliştirilebilir. & 19 \\
\hline & 8) Sosyal ve problem çözme becerileri geliştirmeye yönelik çalışmalar yapılabilir. & 16 \\
\hline & 9) Sanat ve görsel kültüre yönelik çalışmalar yapılabilir. & 16 \\
\hline & 10)Öğretmen öğrencilerin yaparak-yaşayarak öğrenmelerini sağlayabilir. & 15 \\
\hline & 11)Ders materyali ile ders işleniş planı geliştirilebilir. & 14 \\
\hline & 12) Ekinlikler grup çalışmasıyla ve işbirlikli olabilir. & 10 \\
\hline & 13) Üç boyutlu çalışmalar yapılabilir. & 9 \\
\hline & 14) Görsel sanatlar dersine giren öğretmenler branş öğretmeni olabilir. & 8 \\
\hline & 15)Sınıf mevcutları azaltilabilir. & 8 \\
\hline & 16)Ders dışı etkinlikler planlanabilir. & 6 \\
\hline & 17) Görsel sanatlar dersinde öğrenci, performansı ile değerlendirilebilir. & 4 \\
\hline & 18) Görsel sanatlar derslerinde disiplinler arası yaklaşımdan yararlanılabilir. & 3 \\
\hline & 19) Engellilere yönelik çalışmalar ve düzenlemeler yapılabilir. & 3 \\
\hline & 20) Çizgi filmlerin seçiminde uzman ve programcı işbirliği olmalıdır. & 2 \\
\hline & 21)Üniversitelerle işbirliği yapılabilir. & 2 \\
\hline & 22)Sanat eseri incelemesi ve kültürel nesne analizi yapılabilir. & 2 \\
\hline & 23)Okul-veli işbirliği yapılabilir. & 2 \\
\hline & 24)Okullarda sanata yönelik yayınlara yer verilebilir. & 2 \\
\hline & 25) Yetenek derslerinin ders sayısı artırılabilir. & 1 \\
\hline
\end{tabular}


Tablo 11'de araştırma sonuçlarına göre önerilerde en genel belirtilen önerilere yer verilmiştir. En sık ifade edilen öneri hizmet içi eğitim ve seminerlerin verilmesidir. Devamında sıklık sırasına göre yer verilen öneriler şu şekildedir: Sanat öğretimine olanak sağlayan fiziksel donanım -görsel materyal(araç-gereç,atölye,görsel materyal)sağlanabilir, görsel sanatlar dersi programı uygulamaları için ders süresi artırılabilir, müzelerle işbirliği yapılabilir, gsd müfredat programı geliştirilebilir, güncellenebilir, görsel sanatlar dersi işlenişinde öğrencilerin bireysel özelliklerine (farklııklar) dikkat edilebilir, görsel sanatlarda öğretim teknolojileri ve materyal tasarımı geliştirilebilir, sosyal ve problem çözme becerileri geliştirmeye yönelik çalışmalar yapılabilir, sanat ve görsel kültüre yönelik çalışmalar yapılabilir, öğretmen öğrencilerin yaparak-yaşayarak öğrenmelerini sağlayabilir, ders materyali ile ders işleniş planı geliştirilebilir, ekinlikler grup çalışmasıyla ve işbirlikli olabilir, üç boyutlu çalışmalar yapılabilir, görsel sanatlar dersine giren öğretmenler branş öğretmeni olabilir, sınıf mevcutları azaltılabilir, ders dışı etkinlikler planlanabilir, görsel sanatlar dersinde öğrenci, performansı ile değerlendirilebilir, görsel sanatlar derslerinde disiplinler arası yaklaşımdan yararlanılabilir, engellilere yönelik çalışmalar ve düzenlemeler yapılabilir, çizgi filmlerin seçiminde uzman ve programcı işbirliği olmalıdır, üniversitelerle işbirliği yapılabilir, sanat eseri incelemesi ve kültürel nesne analizi yapılabilir, okul-veli işbirliği yapılabilir, okullarda sanata yönelik yayınlara yer verilebilir, yetenek derslerinin ders sayısı artrılabilir.

\section{Tablo 12. Tezlerde araştırmacılara yönelik öneriler}

\begin{tabular}{|c|c|}
\hline \multirow{18}{*}{$\begin{array}{l}\text { Tezlerde araştirmacılara } \\
\text { yönelik öneriler }\end{array}$} & Kod \\
\hline & 1) İleride yapılabilecek çalışmalar farklı öğrenci, seviye grupları üzerinde denenebilir. \\
\hline & 2)Daha geniş bir çerçevede durum tespiti yapılabilir.(Farklı okul-il) \\
\hline & 3)GSDÖP kazanımlarının gerçekleştirilmesine yönelik çalışmalar yapılabilir. \\
\hline & $\begin{array}{l}\text { 4) Öğrenci görüşlerinin yanı sıra öğretmen, uzman, yönetici, ebeveyn görüşleri de alınarak } \\
\text { görsel kültür sanat kültürü-kültür bilinci ve tarih ile ilgili daha kapsamlı araştırmalar yapıla- } \\
\text { bilir. }\end{array}$ \\
\hline & 5) Farklı araştırma desenlerinde de çalışmalar yapılabilir. \\
\hline & 6)Görsel sanatlar müfredatını geliştirmeye yönelik karşılaştırmalı araştırmalar yapılabilir. \\
\hline & $\begin{array}{l}\text { 7) Başarının ölçülmesi adına öğrencilere uygulanabilecek farklı test ve yöntemler geliştirile- } \\
\text { bilir. }\end{array}$ \\
\hline & $\begin{array}{l}\text { 8) Günümüz görsel sanatlar dersi öğretim programlarının, disiplinler arası yaklaşımla ders } \\
\text { işlenmesine uygun olup olmadığı ile ilgili araştırmalar yapılabilir. }\end{array}$ \\
\hline & 9) İşbirliğine dayalı öğrenme yöntemine dayalı yeni araşttrmalar yapılabilir. \\
\hline & 10) Daha uzun süreli olarak araştırmalar yapılabilir. \\
\hline & $\begin{array}{l}\text { 11)Görsel sanatlar dersinin ve müze bilincinin kazandırılmasında yaratıcı drama yönteminin } \\
\text { kullanımına yönelik araştırma yapılabilir. }\end{array}$ \\
\hline & 12)Görsel sanatlar ile başarı ve motivasyon arasındaki ilişki incelenebilir. \\
\hline & 13)Aynı uygulamalar farklı konularda da yapılabilir. \\
\hline & 14) Araştırmaların değişen dünya koşulları nedeniyle tekrarlanması gerekebilir. \\
\hline & $\begin{array}{l}\text { 15) Görsel Sanatlar Dersinde Çalışma Kağıtları Kullanımının dışında faklı öğretim materyalle- } \\
\text { rinin de insan figürü çizimine etkisi ölçülebilir. }\end{array}$ \\
\hline & 16) Eleştirel tutum geliştirmeye yönelik araştırmalar da yapılabilir. \\
\hline & $\begin{array}{l}\text { 17) Görsel sanatlar (resim-iş) dersinin öğrencilerin psikolojisi üzerinde etkileri de geliştirile- } \\
\text { rek bir program ile test edilebilir. }\end{array}$ \\
\hline
\end{tabular}

Tablo 12'de tezlerde araştırmacılara yönelik önerilere bakıldığında en sık belirtilen önerinin ileride yapılabilecek çalışmaların farklı öğrenci ve seviye gruplarıyla yapılabileceği olduğu görülmektedir. Tablonun devamında en sık ifade edilen öneriden en az ifade edilen öneriye bakıldığında şu şekilde sıralanabilir: Daha geniş bir çerçevede durum tespiti yapılabilir, GSDÖP kazanımlarının gerçekleştirilmesine yönelik çalışmalar yapılabilir, öğrenci görüşlerinin yanı sıra öğretmen, uzman, yönetici, ebeveyn görüşleri de alınarak görsel kültür sanat kültürü-kültür bilinci ve tarih ile ilgili daha kapsamlı araştırmalar yapılabilir, farklı araştırma desenlerinde de çalışmalar yapılabilir, görsel sanatlar müfredatını geliştirmeye yönelik karşılaştırmalı araştırmalar yapılabilir, başarının ölçülmesi adına öğrencilere uygulanabilecek farklı test ve yöntemler geliştirilebilir, günümüz görsel sanatlar dersi öğretim programlarının, disiplinler arası yaklaşımla ders işlenmesine uygun olup olmadığı ile ilgili araştırmalar yapılabilir, işbirliğine dayalı öğrenme yöntemi kapsamlı ele alınarak yeni araştırmalar yapılabilir, daha uzun süreli olarak araştırmalar yapılabilir, görsel sanatlar dersinin ve müze bilincinin kazandırılmasında yaratıcı drama yönteminin kullanımına yönelik araştırma yapılabilir, görsel sanatlar ile başarı ve motivasyon arasındaki ilişki incelenebilir, aynı uygulamalar farklı konularda da yapılabilir, araştırmaların değişen dünya koşulları nedeniyle tekrarlanması gerekebilir, görsel sanatlar dersinde çalışma kağıtları kullanımının dışında faklı 
öğretim materyallerinin de insan figürü çizimine etkisi ölçülebilir, eleştirel tutum geliştirmeye yönelik araştırmalar da yapılabilir, görsel sanatlar (resim-iş) dersinin öğrencilerin psikolojisi üzerinde etkileri de incelenebilir.

Tablo 13. Tezlerde kullanılan anahtar kelimeler

\begin{tabular}{llc}
\hline & Kod & Frekans \\
\cline { 2 - 3 } & Sanat eğitimi & 18 \\
& Görsel sanatlar & 9 \\
& Görsel sanatlar dersi & 9 \\
& Görsel sanatlar eğitimi & 8 \\
& Yaratıcılık & 6 \\
& Sanat & 6 \\
Tezlerdeki anahtar kelimeler & İlköğretim & 4 \\
& İlkörlikli öğretim & 3 \\
& Görsel sanatlar öğretmeni & 3 \\
& Geleneksel öğretim & 2 \\
& Tutum & 2 \\
& Müze & 2 \\
& Görsel sanatlar dersi öğretim programı & 2 \\
& Yapılandırmacılık & 2 \\
& Yaratıcı drama & 2 \\
& Diğer & 2 \\
\hline
\end{tabular}

Tablo 13'de tezlerde kullanılan anahtar kelimelere bakıldığında en sık olarak 'sanat eğitimi' anahtar kelimesinin kullanıldığı görülmektedir. Devamında tekrar edilme sıklı̆ıında en çoktan aza doğru sıralandığında; görsel sanatlar, görsel sanatlar dersi, görsel sanatlar eğitimi, yaratıcılık, sanat, ilköğretim, işbirlikli öğrenme, ilköğretim, görsel sanatlar öğretmeni, geleneksel öğretim, tutum, müze, görsel sanatlar dersi öğretim programı, yapılandırmacılık, yaratıcı olduğu görülmektedir. Diğer anahtar kelimeler de; drama,Figür,Materyal tasarımı,Sanatsal düzenleme ilkesi, bilişsel,duyuşsal, devinişsel, görsel kültür, sanat eleştirisi,algı,imge,temsil,afiş tasarımı,tasarım ilkeleri,tasarım elemanları,demokrasi,demokrasi eğitimi,okul yöneticileri,üç boyutlu biçimlendirme,biçimlendirme,nesnel gerçeklik, ilköğretim görsel sanatlar müfredat, işbirliğine dayalı öğrenme yöntemi, bireysel öğrenme, dijital kültür, motivasyon, kazanım, içerik, öğretme-öğrenme süreci, ölçme değerlendirme süreci, tarih ve kültür bilinci, disipline dayalı sanat eğitimi, öğretim programı, öğretmen görüşleri, köy okulu, kent okulu, öğretmen, öğretim programı geliştirme, empati, iletişim, işitme engelli çocuklar, görsel sanatlar kültürü, müze eğitimi, kültür bilinci, perspektif, işbirliğine dayalı öğrenme, temel tasarım, afiş, grafik tasarımı, işbirlikli öğrenme yöntemi,hikaye, hikaye anlatım yöntemi, disiplinler arası yaklaşım, işbirlikçi öğrenme, grup çalışması, doğanşehir, ilköğretim görsel sanatlar öğretimi,küçük grup çalışması, üç boyutlu sanal müze ziyareti, sanal müze ziyareti, ilköğretim de üç boyutlu sanal müze ziyareti, müze bilinci, müzede yaratıcı drama, desen, obje, beşinci sınıf öğrencileri, kontrol grubu, deney grubu, tutum ölçeği, sevgi içerikli çizgi filimler, çocuk becerisi, çizgi filmin etkileri, hastane ilköğretim okulu, hasta çocuklar, görme engelliliği, görmenin ötesinde sanat, sürrealizm, görme engellilerin sanat eğitimi, dokunma ve dinleme yoluyla sanat eğitimi, üç boyutluluk, matematik öğretimi, geleneksel öğretim, çoklu zeka kuramı, zeka,portre,proje, geleneksel yöntem, proje tabanlı öğrenme olarak görülmektedir. 
Tablo 14. Tezlerde kullanılan dizinler

\begin{tabular}{|c|c|c|}
\hline & Kod & Frekans \\
\hline & Görsel sanatlar dersi & 13 \\
\hline & Görsel sanatlar eğitimi & 13 \\
\hline & Sanat eğitimi & 12 \\
\hline & İlköğretim okulları & 10 \\
\hline & Görsel sanatlar & 6 \\
\hline & İlköğretim öğrencileri & 6 \\
\hline & Müze eğitimi & 5 \\
\hline & İlköğretim & 4 \\
\hline & Ders programları & 4 \\
\hline & Illköğretim öğretmenleri & 3 \\
\hline Tezlerde kullanılan dizinler & Sanat & 2 \\
\hline & Resim-iş eğitimi & 2 \\
\hline & Resimler & 2 \\
\hline & Kültür & 2 \\
\hline & İşbirlikli öğrenme & 2 \\
\hline & Eğitim & 2 \\
\hline & Materyal kullanımı & 2 \\
\hline & Ortaokul öğrencileri & 2 \\
\hline & Sınıf öğretmenleri & 2 \\
\hline & Öğretmenler & 2 \\
\hline & Dizin olmayan tezler & 17 \\
\hline & Diğer & 41 \\
\hline
\end{tabular}

Tablo 14'te tezlerde kullanılan dizinlere bakıldığında en sık tekrar edilen dizin kelimelerinden en az tekrar edilene doğru şu şekilde sıralandığı görülmektedir: Görsel sanatlar dersi, görsel sanatlar eğitimi, sanat eğitimi, ilköğretim okulları, görsel sanatlar, ilköğretim öğrencileri, müze eğitimi, ilköğretim, ders programları, ilköğretim öğretmenleri, sanat, resim-iş eğitimi, resimler, kültür , işbirlikli öğrenme, eğitim, materyal kullanımı, ortaokul öğrencileri, sınıf öğretmenleri, öğretmenler. Dizini olmayan 17 tane tez ile diğer dizinlere yer verildiği 41 tane tez bulunmaktadır. Sözü edilen diğer dizin kelimeleri şu şekildedir: Ortaokullar, tutumlar, çocuk gelişimi, öğrenci tutumu, portre, resim öğretimi, görsel kültür, popüler kültür, branş öğretmenleri, kopyalama, sanatsal yaratıcılık,yaratıcılık, bayramlar, değerler, değerler eğitimi, milli bilinç,milli şuur, analiz,sanat eseri,sanat eleştirisi, öğretim programları, öğretmen görüşleri, müzeler, CD, teknoloji, teknoloji kullanımı, öğretim, öğretim yöntemleri, interaktif öğretim,öğrenme, görsel-işitsel materyaller, çevre, çevre bilinci, çevre eğitimi,müzecilik, renkler,renk anlatımı, a takımı.

\section{Tablo 15. Tezlerin araştırmacı cinsiyeti}

\begin{tabular}{llc}
\hline \multirow{3}{*}{ Araştırmacı cinsiyeti } & Kod & Frekans \\
\cline { 2 - 3 } & Kadın & 64 \\
& Erkek & 20 \\
\hline
\end{tabular}

Tablo 15 'te tezlerin araştırmacı cinsiyetine bakıldığında 64 tez yazarının kadın, 20 tez yazarının da erkek olduğu görülmektedir. Tablo 4'te tezlerin bölümlere göre dağılımına bakıldığında, tezlerin büyük bir kısmının resim-iş öğretmenliği ve ilgili bölümler ile sınıf öğretmenliğinde üretildiği görülmektedir. Eğitim fakültelerinde bu bölümlerde öğrenci / öğretmen adaylarına bakıldığında büyük oranda cinsiyeti kadın olan bireylerden oluştuğu düşünülürse, bu bulgunun da beklendik bir bulgu olduğu söylenebilir.

\section{Tablo 16.Tezlerin kaynakça sayısı}

\begin{tabular}{llc}
\hline & Kod & Frekans \\
\cline { 2 - 3 } K1-100 & 47 \\
Kaynakça sayısı & $1-50$ & 21 \\
& $101-150$ & 11 \\
& $151-200$ & 3 \\
& $201-250$ & 1 \\
\hline
\end{tabular}


Tablo 16'da tezlerin kaynakça sayısına bakıldığında 47 tezde 51-100 arası kaynakça, 21 tezde 1-50 arası, 11 tezde 101-150 arası, 3 tezde 151-200 arası ve 1 tezde de 201-250 arası kaynakça kullanıldığı görülmektedir. İlköğretimde görsel sanatlarla ilgili tez yazımında kaynakça yazımında kullanılan kaynak sayısının büyük oranda 51-100 arasında değiştiği görülmektedir.

Tablo 17.Tezlerin yerli kaynakça sayısı

\begin{tabular}{llc}
\hline & Kod & Frekans \\
\cline { 2 - 3 } Y1-100 & 44 \\
Yerli kaynak sayısı & $1-50$ & 32 \\
& $101-150$ & 7 \\
& $151-200$ & 1 \\
& $201-250$ & 0 \\
\hline
\end{tabular}

Tablo 17'de tezlerin yerli kaynakça sayısına bakıldığında 44 tane tezde 51-100 arası, 32 tezde 1-50 arası, 7 tezde 101150 arası, 1 tezde de 151-200 arası yerli kaynakça kullanıldığı görülmektedir.

Tablo 18.Tezlerin yabancı kaynakça sayısı

\begin{tabular}{llc}
\hline & Kod & Frekans \\
\cline { 2 - 3 } Yabancı kaynak sayısı & $51-100$ & 83 \\
& $101-150$ & 1 \\
& $151-200$ & 0 \\
& $201-250$ & 0 \\
\end{tabular}

Tablo 18 'de tezlerin yabancı kaynakça sayısına bakıldığında 83 tezde 1-50 arası, 1 tezde de 51-100 arası yabancı kaynakça kullanıldığı, tablo 17'deki yerli kaynakça sayısına oranla büyük fark görülmektedir. Bunun da eğitim fakültelerinde ilköğretimde görsel sanatlar ile ilgili tezlerin yazıldığı bölümlerde büyük oranda Türkçe dilinde eğitim verilmesi ile ilgili olabileceği söylenebilir.

\section{Sonuçlar}

Geçmişten 2016 yılına kadar ilköğretimde görsel sanatlar ile ilgili yapılan tezlerden elde edilen veriler, makalenin bulgular bölümünde ayrıntılı biçimde yorumlanmıştı. Araştrrma sonuçlarına bu bölümde yer verilmiştir. Tezlerin danışman unvanına göre dağıımına bakıldığında, incelenen tezler içerisinde danışmanlık yapan öğretim üyelerinden 45 Yrd. Doç. Dr., 31 Prof. Dr. ve 8 Doç. Dr. olduğu görülmüştür. Tezlerin basıldığı tarihe göre dağılımına bakıldığında konu ile ilgili en fazla tezin 2011 yılında, onu takiben 2010 ve 2009 yılında yapıldığı görülmektedir. 2005 yılından bugüne konu ile ilgili tez yazımında bir artı̧ olduğu görülmektedir. Tezlerin yazıldığı üniversiteye göre dağııımlarına bakııdığında konu ile ilgili tezlerin en fazla üretildiği üniversitenin Gazi Üniversitesi, onu takiben Marmara Üniversitesi, Anadolu Üniversitesi, Çanakkale 18 Mart Üniversitesi, 19 Mayıs Üniversitesi olduğu görülmüştür. Tezlerin bölümlere göre dağılımına bakıldığında ilköğretimde görsel sanatlara ilişkin en çok üretilen tezlerin resim-iş öğretmenliği, resim-iş eğitimi, güzel sanatlar eğitimi ve sınıf öğretmenliği olduğu görülmektedir. 2016 yılına kadar sınıf öğretmenliğinde 4 tane tez üretildiği görülmüştür. Tezlerin lisansüstü düzeyine göre dağılıma bakıldığında görsel sanatlarla ilgili yapılan tezlerin 69 tanesinin yüksek lisans, 15 tanesinin de doktora düzeyinde olduğu görülmüştür. Illköğretim düzeyinde görsel sanatlarla ilgili tezlerin yöntemine göre dağılımına bakıldığında toplam 84 tez içerisinden 46 tanesinde nitel, 39 tanesinde ise nicel araştrrma yöntemlerinin kullanıldığı görülmüştür. Tezlerde çalışma grubu seçimine bakıldığında, incelenen 84 lisansüstü tez içerisinden 61 tanesinde ilköğretim öğrencileriyle, 14 tanesinde görsel sanatlar öğretmenleriyle, 6 tanesinde sınıf öğretmenleriyle, 3 tanesinde resim öğretmenleriyle, müdür ve müdür yardımcılarıyla, 1tanesinde öğretim elemanları, üniversite öğrencileri ve velilerle çalışılmıştır. Illköğretimde görsel sanatlarla ilgili yapılan lisansüstü tezlerin çalışma grubu düzeyine bakıldığında en sık 6. ve 7.Sınıf öğrencileriyle, en az 1. ve 2. Sınıf düzeyindeki öğrencilerle yapıldığı görülmektedir. Tezlerin çalışma grubu büyüklüğüne bakıldığında ilköğretimde görsel sanatlarla ilgili olarak tezlerin büyük bir kısmında (39 tane tezde) çalışma grubu olarak 1-50 arası katlımcı seçildiği, yalnızca 1 tezde 501 ve üstü katılımcı ile çalışıldığı görülmektedir. İlköğretimde görsel sanatlarla ilgili tezlerde kullanılan veri toplama araçlarına bakıldığında, nitel ve nicel veri toplama araçlarının olduğu görülmektedir. Nitel veri toplama araçları olarak en sık anket, görüşme, yapılandırılmış-yapılandırımamış form, doküman inceleme, işitsel ve görsel araç-gereçler ve gözlem kullanıldığı görülmektedir. Nicel veri toplama araçlarından tutum ölçeği, başarı testi ile diğer ölçeklerin kullanıldığı görülmektedir. 
İncelenen tezlerde verilen önerilere bakıldığında en sık ifade edilen önerinin hizmet içi eğitim ve seminerlerin verilebileceği olduğu görülmüştür. Sanat öğretimine olanak sağlayan fiziksel donanımın - görsel materyallerin sağlanması, görsel sanatlar dersi programı uygulamaları için ders süresinin artırılması, müzelerle işbirliği yapılması, görsel sanatlar dersi öğretim programının geliştirilmesi ve güncellenmesi, görsel sanatlar dersi işlenişinde öğrencilerin bireysel özelliklerine dikkat edilmesi, görsel sanatlarda öğretim teknolojileri ve materyal tasarımının geliştirilmesi, incelenen tezlerde sıkıkla belirtilen öneriler arasında yer almaktadır. Tezlerde kullanılan anahtar kelimelere bakıldığında en sık olarak 'sanat eğitimi' anahtar kelimesinin kullanıldığı görülmektedir. En sık tekrar edilen anahtar kelimelerin devamında; 'görsel sanatlar, görsel sanatlar dersi, görsel sanatlar eğitimi, yaratıcılık, sanat, ilköğretim, işbirlikli öğrenme, ilköğretim, görsel sanatlar öğretmeni, geleneksel öğretim, tutum, müze, görsel sanatlar dersi öğretim programı, yapılandırmacılık, yaratcı' kavramlarının olduğu görülmektedir. Tezlerde kullanılan dizinlere bakıldığında en sık tekrar edilen dizin kelimelerinin 'görsel sanatlar dersi, görsel sanatlar eğitimi, sanat eğitimi, ilköğretim okulları, görsel sanatlar, ilköğretim öğrencileri, müze eğitimi, ilköğretim, ders programları, ilköğretim öğretmenleri, sanat, resim-iş eğitimi, resimler, kültür , işbirlikli öğrenme, eğitim, materyal kullanımı, ortaokul öğrencileri, sınıf öğretmenleri, öğretmenler' olduğu görülmüştür.

Tezlerin araştırmacı cinsiyetine bakıldığında 64 tez yazarının kadın, 20 tez yazarının da erkek olduğu görülmüştür. Bu araştırma kapsamında incelenen tezlerin bölümlere göre dağılımına bakıldığında, tezlerin büyük bir kısmının resim-iş öğretmenliği ve ilgili bölümler ile sınıf öğretmenliğinde üretildiği görülmüştür. Tezlerin kaynakça sayısına bakıldığında 47 tezde 51-100 arası kaynakça, 21 tezde 1-50 arası, 11 tezde 101-150 arası, 3 tezde 151-200 arası ve 1 tezde de 201-250 arası kaynakça kullanıldığı görülmüştür. Illköğretimde görsel sanatlarla ilgili tez yazımında kaynakça yazımında kullanılan kaynak sayısının büyük oranda 51-100 arasında değiştiği görülmüştür. Tezlerin yerli kaynakça sayısına bakıldığında 44 tane tezde 51-100 arası, 32 tezde 1-50 arası, 7 tezde 101-150 arası, 1 tezde de 151-200 arası yerli kaynakça kullanıldığı görülmüştür. Tezlerin yabancı kaynakça sayısına bakıldığında 83 tezde 1-50 arası, 1 tezde de 51-100 arası yabancı kaynakça kullanıldığı belirlenmiştir, kullanılan yerli kaynakça sayısıyla yabancı kaynak sayısı arasında büyük fark olduğu görülmüştür.

\section{5. Öneriler}

Bu araştırma sonuçlarından yola çıkarak, temel eğitim düzeyinde görsel sanatlarla ilgili araştırmalara daha fazla yer verilmesi önerilmektedir. Sanata yönelik ilgi, tutum ve farkındalığın oluşacağı ve şekilleneceği temel eğitimde, görsel sanatlarla ilgili yapılacak olan nitel, nicel ya da her iki araştırma yönteminin de birlikte kullanılacağı araştırmalara farkı düzey, çalışma grubu ve değişkenler kullanılarak eğilimin artması sağlanabilir. Özellikle temel eğitimde görsel sanatlarla ilgili yapılacak olan deneysel uygulamaların alan yazına ve öğrencilerin sanata yönelik tutumlarının şekillenmesine büyük katkı sağlayacağı düşünülmektedir. Temel eğitimde görsel sanatlar derslerinin uygulanmasında karşılaşılan güçlüklere ilişkin çözüm oluşturabilecek araştırmaların yapılması önerilebilir. İncelenen tezlerin sonuçlarından yola çıkarak, temel eğitim düzeyinde görsel sanatlar eğitimindeki eksikliklerine giderilmesine yönelik yeni araştırmaların yapılması önerilebilir.

\section{Kaynakça}

Alakuş, A. O. ve Mercin, L. (2009). Sanat Eğitimi ve Görsel Sanatlar Öğretimi, Ankara: Pegem Yayınevi.

Alakuş, A.O (2009). Eğitsel Eleştiri. Alakuş, A.O ve Mercin, L. (Editör), Sanat Eğitimi ve Görsel Sanatlar Öğretimi (s.57-58).Ankara: Pegem Yayınevi.

Altınkurt, L. (2007). Sanat eğitimi ile ilgili lisansüstü tezlerin incelenmesi. Milli Eğitim, 173, 105-113.

Artut, K. (2006). Sanat Eğitimi Kuramları ve Yöntemleri, Ankara: Anı Yayıncılık.

Aydın, A. ve Uysal, Ş. (2014). Türkiye'de eğitim yönetimi teftişi planlaması ve ekonomisi alanındaki doktora tezlerinin incelenmesi, Abant İzzet Baysal Üniversitesi Eğitim Fakültesi Dergisi, 14 (1), 177-201.

Bağ, H. ve Çalık, M. (2017). İlköğretim düzeyinde yapılan argümantasyon çalışmalarına yönelik tematik içerik analizi, Eğitim ve Bilim. 42(190), 281303.

Bağ, H., Kara, İ., \& Uşak, M. (2002). Kimya ve fizik eğitimiyle ilgili makaleler bibliyografyası. Pamukkale Üniversitesi Ĕgitim Fakültesi Dergisi, 2(12), 48-59.

Cavas, B., Cavas, P., Ozdem, Y. Rannikmae, M., \& Ertepinar, H. (2012). Research Trends in Science Education from the Perspective of Journal of Baltic Science Education: A Content Analysis from 2002 to 2011. Journal of Baltic Science Education, 11 (1), 94-102.

Cavitt, M. E. (2006). A content analysis of doctoral research in beginning band education, 1958-2004. Journal of Band Research, 42(1), 42-58.

Chang, P. L., \& Hsieh, P. N. (1997). A qualitative review of doctoral of dissertation management in Taiwan. Higher Education, $33,115-136$.

Çakmakçı, G. (2006). Science education in turkey: a bibliography on teaching and learning science. http://www.geocities.ws/scienceeducationinturkey/eduTurk.pdf 
Çalık, M., Ünal, S., Coştu, B., \& Karataş, F. Ö. (2008). Trends in Turkish Science Education. Essays in Education, Special Edition, 23-46.

De Jong, O. (2007). Trends in western science curricula and science education research: A Bird's eye view. Journal of Baltic Science Education, 6(1), 15-21.

Doğru, M., Gençosman, Tuna, Ataalkın, A.N. ve Şeker, F. (2012). Fen bilimleri eğitiminde çalışılan yüksek lisans ve doktora tezlerinin analizi. Türk Fen Eğitimi Dergisi, 9(1): 49-64.

Fışkın, R., \& Nas, S. (2013). A Content Analysis of the International Journal on Marine Navigation and Safety of Sea Transportation from 2007 to 2012.Trans. Nav. Journal, 7(1), 145-149.

Gençaydın, Z. (2002). Sanat Eğitimcisi Yetiştirmede G.E.E. Resim-İş Bölümünün Yeri ve Bugünkü Durumu Üstüne. Gazi Üniversitesi'nin Eğitimde 75. Yılı Sanat Eğitimi Sempozyumu. Ankara: Gazi Üniversitesi Illetişim Matbaası.

Gökay, M (2009). Görsel Sanatlar Eğitimi.Alakuş, A.O \& Mercin, L (Eds.), Sanat Eğitimi ve Görsel Sanatlar Öğretimi (s.13-18).Ankara: Pegem Yayınevi.

Gökay, M (2010). Sanat Kitabım Sanata Ilk Adım. Konya: Aybil Yayıncılık.

Guo Z., \& Sheffield J. (2008). A paradigmatic and methodological examination of knowledge management research: 2000 to 2004 . Decision Support Systems, 44, 673-688.

http:// oc.eab.org.tr/egtconf/pdfkitap/pdf/488.pdf.

Hüseyinbaş, Ö., Çalap, G., ve Kurnaz, M.A. (2018). Kastamonu eğitim dergisinde 2010-2016 yılları arasında yayınlanan makalelerin analizi. Kastamonu Eğitim Dergisi, 26(1), 231-240. doi:10.24106/kefdergi.378337

Juodaitytė, A., \& Kazlauskienè, A. (2008). Research methods applied in doctoral dissertations in education science (1995-2005): Theoretical and empirical analysis. Vocational Education: Research \& Reality, 15, 36-45.

Kayhan, M., \& Koca, S. (2004). Matematik eğitiminde araştırma konuları: 2000-2002. Hacettepe Üniversitesi Eğitim Fakültesi Dergisi, $26,72-81$. Kırışoğlu, O. T. (2009). Sanat Kültür Yaratıcılık - Görsel Sanatlar ve Kültür Eğitimi Öğretimi, Ankara: Pegem Yayınevi.

Miles, M. B. ve Huberman, A. M. (1994). Qualitative data analysis: An expanded sourcebook. Thousand Oaks, Sage.

Oruç, Ş., \& Ulusoy, K. (2008). Sosyal bilgiler öğretimi alanında yapılan tez çalışmaları. Selçuk Üniversitesi Ahmet Keleşoğlu Eğitim Fakültesi Dergisi, 26, 121-132.

Özsoy, V (2016). Görsel Sanatlar Eğitimi Makaleler. (2. Baskı) Ankara: Pegem Akademi.

Öztürk, R. (1994). Sanata Duyulan ilgi Düzeyi ile Demokratik Tutum Arasındaki İlişki. Yüksek Lisans Tezi, Ankara Üniversitesi, Ankara.

Pasin, G. (2004). Lise Sanat Etkinliklerini İzleme 11. Sınıf, İstanbul: MEB Yayınları.

Pekmezci, H. (1997). İlköğretim Okullarında Sanat Eğitimine Toplu Bakış - İlköğretim Okullarında Sanat Eğitimi ve Sorunları. Türk Eğitim Derneği XV. Öğretim Toplantısı, Kayseri: Gün Ofset Matbaacılık.

Read, H. (1984). The Meaning of Art, London: Faber \& Faber.

San, İ. (1979). Sanatsal Yaratma ve Çocukta Yaratıcılık, Ankara: Türkiye İş Bankası Kültür Yayınları.

San, i. (1983). Sanat Eğitimi Kuramları, Ankara: Tan Yayınları.

San, ì. (2008). Sanat ve Eğitim, Ankara: Ütopya Yayınevi.

Sert, G., Kurtoğlu, M., Akıncı, A., \& Seferoğlu, S. S. (2012, Şubat). Öğretmenlerin teknoloji kullanma durumlarını inceleyen araştırmalara bir bakış: Bir içerik analizi çalışması. Akademik Bilişim, Uşak.

Sözbilir, M., Kutu, H., \& Yaşar, M. D. (2012). Science education research in Turkey: A content analysis of selected features of papers published. In J. Dillon\& D. Jorde (Eds). The World of Science Education: Handbook of Research in Europe (pp.341-374). Rotterdam: Sense Publishers.

Şara, P.,Karadedeli, i. \&Hasanoğlu, G. (2016). Sınıf yönetimi alanında ulakbim'de taranan makalelerin incelenmesi. Kırıkkale Üniversitesi Sosyal Bilimler Dergisi, 6 (2), 291-306.

Wassink F., \& Sadi, Ö. (2016). Türk fen bilimleri eğitiminde araştırma ve yönelimler: 2005-2014 yılları arası bir içerik analizi. İlköğretim Online, 15(2), 594-614.

Williams, M. E., \& Buboltz, W. C. (1999). Content Analysis of the Journal of Counseling \& Development. Journal of Counseling \& Development, 77(3), 344-349

Yalçın, N.,Bilican, S., Kezer, F. \& Yalçın, Ö. (2009). Hacettepe üniversitesi eğitim fakültesi dergisinde yayımlanan makalelerin niteliği: İçerik analizi. Retrieved December 6 2009,

\section{EK-1 INCELENEN YAYIN LISTESi}

Akengin, Ç (2011). Illköğretim 6. sınıf görsel sanatlar dersinde müze kaynaklı işbirliğine dayalı öğretim yönteminin öğrenci kazanımlarına etkisi ( Yayınlanmamış doktora tezi). Gazi Üniversitesi, Ankara.

Akgül, B (2013). İlköğretim görsel sanatlar dersinde akıllı tahta kullanımının öğrenci başarısına etkisi (Yayınlanmamış yüksek lisans tezi). Gazi Üniversitesi, Ankara.

Akın, N (2009). Illköğretim 6. sınıf görsel sanatlar dersinde işbirlikli öğrenmenin renk konusunun işlenişinde öğrenci başarısına etkisi (Yayınlanmamış yüksek lisans tezi). Marmara Üniversitesi, İstanbul. 
Akyıldız, F (2006). İlköğretim okullarında (9-12 yaş) görsel sanatlar dersi kapsamında renk bilgisinin kavratılmasındaki sorunlar ve çözüm önerileri (Yayınlanmamış yüksek lisans tezi). Ondokuz Mayıs Üniversitesi, Samsun.

Akyürek, T (2011). Illköğretim 1. kademe görsel sanatlar dersinde müze eğitiminin tarih ve kültür bilinci oluşturmasındaki önemi (Yayınlanmamış yüksek lisans tezi) Gazi Üniversitesi, Ankara.

Alan, i (2009). Sevgi içerikli çizgi filmlerin ilköğretim 5. sınıftaki çocukların görsel sanatlar dersinde yaptıkları resimler üzerindeki etkisinin incelenmesi (Yayınlanmamış yüksek lisans tezi) Gazi Üniversitesi, Ankara.

Altay, L (2009). İlköğretim ikinci kademe altıncı sınıf görme engelli öğrencilerin görsel sanatlar eğitimine yönelik bir inceleme (Yayınlanmamış yüksek lisans tezi). Gazi Üniversitesi, Ankara.

Arslan, D (2012). Illköğretim ikinci kademe görsel sanatlar dersi hakkında okul yöneticilerinin görüşleri :Ankara ili örneği (Yayınlanmamış yüksek lisans tezi). Anadolu Üniversitesi, Eskişehir.

Aslan, E (2011). İlköğretim 1. kademe görsel sanatlar uygulamalarında motivasyonun yeri ve önemi (Yayınlanmamış yüksek lisan tezi). Gazi Üniversitesi, Ankara.

Aslantaş, S (2008). Illköğretim II. kademe proje tabanlı öğrenme yönteminin görsel sanatlar dersine katkısı (Yayınlanmamış yüksek lisans tezi). Gazi Üniversitesi, Ankara.

Atalay, N (2011). illköğretim I. kademede müze eğitiminin görsel sanatlar kültürüne etkileri (Yayınlanmamış doktora tezi). Marmara Üniversitesi, İstanbul.

Ateş, R (2007). Illköğretim 7-11 yaş grubu için görsel sanatlar dersinin önemi (Yayınlanmamış yüksek lisans tezi). Marmara Üniversitesi, İstanbul.

Batur, M (2010). İlköğretim I. kademe görsel sanatlar dersi öğretim programının kazanımlar boyutunun öğretmen görüşlerine göre değerlendirilmesi (Yayınlanmamış yüksek lisans tezi). Çanakkale Onsekiz Mart Üniversitesi, Çanakkale.

Beşen, S (2012). Illköğretim okulları görsel sanatlar eğitimi dersinde bireysel ve işbirlikçi öğrenmenin öğrenci üzerindeki etkisi (Yayınlanmamış yüksek lisans tezi). Gazi Üniversitesi, Ankara.

Bozok, B (2011). İlköğretim 8. sınıf görsel sanatlar dersinde milli değerler kazanılmasında milli bayramlarımızın etkisi (Yayınlanmamış yüksek lisans tezi). Gazi Üniversitesi, Ankara.

Canlı, K (2016). illkokul 4. sınıf görsel sanatlar dersinde sanal müze uygulamasına ilişkin öğretmen, öğrenci ve veli görüşleri (Yayınlanmamış yüksek lisans tezi). Necmettin Erbakan Üniversitesi, Konya.

Coşkun, O (2007). Illköğretim okullarında görsel sanatlar dersinde bilgisayarla grafik tasarım uygulamaları üzerine bir değerlendirme (Yayınlanmamış yüksek lisans tezi). Dokuz Eylül Üniversitesi, İzmir.

Çakan, Y (2011). Illköğretim 7. sınıf görsel sanatlar dersi röprodüksiyon konusunun, müze eğitim atölyeleri ortamında işlenmesinin incelenmesi (Yayınlanmamış yüksek lisans tezi). Marmara Üniversitesi, İstanbul.

Demirel Aksoy, N (2010). Postmodern sanat eğitimi kapsamında ilköğretim görsel sanatlar eğitiminin değerlendirilmesi ve programın yeniden yapılandırııması için öneriler (Yayınlanmamış doktora tezi). Ankara Üniversitesi, Ankara.

Demirel, i (2011). Köy ve kent okullarında öğrenim gören ilköğretim II. kademe öğrencilerinin görsel sanatlar dersine ilişkin tutumlarının karşılaştırılması (Yayınlanmamış yüksek lisans tezi). Karadeniz Teknik Üniversitesi, Trabzon.

Deveci Danış, E (2007). Illköğretim ikinci kademe görsel sanatlar eğitimi estetik beğeninin geliştirilmesinde materyal kullanımının yeri, önemi ve uygulanması (Yayınlanmamış yüksek lisans tezi). Selçuk Üniversitesi, Konya.

Diğler, M (2011). illköğretim 7. sınıflar görsel sanatlar dersinde perspektifin işbirliğine dayalı ve geleneksel öğretim yöntemiyle işlenmesinin öğrenci tutum ve başarılarına etkisi (Yayınlanmamış doktora tezi). Gazi Üniversitesi, Ankara.

Dilli, R (2013). Görsel kültür kuramının ilköğretim 4. sınıf görsel sanatlar dersinde uygulanması (Yayınlanmamış doktora tezi). Gazi Üniversitesi, Ankara.

Dorukan, N (2009). İlköğretim kurumlarındaki görsel sanatlar dersinin uygulamaları ve sonuçları (Yayınlanmamış yüksek lisans tezi). Marmara Üniversitesi, İstanbul.

Duman, A (2013). İlkokul 4. sınıf öğrencilerinin eğitsel oyunlarla görsel sanatlar dersine olan ilgilerinin belirlenmesi (Yayınlanmamış yüksek lisans tezi). Gazi Üniversitesi, Ankara.

Durmuş, N (2009). Görsel sanatlar eğitiminin ilköğretim I. kademedeki öğrencilerde çevre bilinci düzeylerinin gelişmesine katkısı (Yayınlanmamış yüksek lisans tezi). Gazi Üniversitesi, Ankara.

Dutkin, A (2012). İlköğretim ikinci kademede verilen görsel sanatlar dersinin algılanma düzeyinin araştrılması (Yayınlanmamış yüksek lisans tezi). Çanakkale 18 Mart Üniversitesi, Çanakkale.

Ermiş, B (2010). İlköğretim 6.sınıf öğrencilerinin görsel sanatlar dersinde (üç boyutlu sanal müze ziyareti) etkinliğine ilişkin görüşleri (Yayınlanmamış yüksek lisans tezi). Gazi Üniversitesi, Ankara.

Ertürk, M. (2011). İlköğretim II. kademe görsel sanatlar eğitimi dersi öğretim programının öğretmen görüşlerine göre değerlendirilmesi (Yayınlanmamış yüksek lisans tezi). Uludağ Üniversitesi, Bursa.

Fidan, S (2013). illköğretim 2. kademe görsel sanatlar dersi öğretim programı öğrenme alanlarının öğretme-öğrenme sürecine yansıma düzeyine ilişkin öğretmen görüşleri :Bursa ili örneği (Yayınlanmamış yüksek lisans tezi). Çanakkale 18 Mart Üniversitesi, Çanakkale.

Gökmen, S (2016). İlköğretim 6. sınıf öğrencilerinin hayalden insan figürü çizmelerine görsel sanatlar eğitiminin etkisi (Yayınlanmamış yüksek lisans tezi). Gazi Üniversitesi, Ankara. 
Göknur, Ş (2011). Illköğretim II. kademe görsel sanatlar öğretim programının kazanımlar boyutunun öğretmen görüşlerine göre değerlendirilmesi (Yayınlanmamış yüksek lisans tezi). Çanakkale 18 Mart Üniversitesi, Çanakkale.

Güler, M (2011). İlköğretim 7. sını öğrencilerinde görsel sanatlar dersinde kültür bilincini geliştirme (Yayınlanmamış yüksek lisans). Marmara Üniversitesi, İstanbul.

İldanlı, D (2010). İlköğretim okullarının II. kademesinde görsel sanatlar dersi haftalık ders saati süresinin yeterliğinin araştırılması (Yayınlanmamış yüksek lisans tezi). Selçuk Üniversitesi, Konya.

İnci, H (2012). illköğretim görsel sanatlar dersinde yer alan üç boyutlu biçimlendirme çalışmalarının nesnel gerçeklik basamağındaki öğrencilerin özgüven gelişimlerine katkısı (Yayınlanmamış yüksek lisans tezi). 19 Mayıs Üniversitesi, Samsun.

İncirkuş, B (2014). İlköğretim ikinci kademe öğrencilerine verilen görsel sanatlar dersindeki portre ve otoportre çalışmalarının öğrenciler üzerindeki etkisi (Yayınlanmamış yüksek lisans tezi). Marmara Üniversitesi. İstanbul.

Kahraman, M (2010). İlköğretim 8. sınıf görsel sanatlar dersi programında yer alan "eser analizi" konusunun sanatsal öğretime katkısı nedir? (Yayınlanmamış yüksek lisans tezi). Marmara Üniversitesi, İstanbul.

Kahvecioğlu, N (2007). İlköğretim II. sınıf görsel sanatlar dersinde bilgisayar destekli öğretim ve geleneksel öğretim yöntemlerinin öğrenme üzerindeki etkisinin karşılaştırılması (Yayınlanmamış yüksek lisans tezi). Gazi Üniversitesi, Ankara.

Kalkan A (2016). ilkkokul öğretmenlerinin görsel sanatlar dersindeki üç boyutlu çalışmalara ilişkin materyal kullanımı Sabundan heykel örneği (Yayınlanmamış yüksek lisans tezi). Marmara Üniversitesi, İstanbul.

Kalyoncu, R (2009). İlköğretim 8. sınıf görsel sanatlar dersi kent projesi konusunda proje tabanlı öğrenmeye dayalı bir uygulama örneği (Yayınlanmamış doktora tezi). Gazi Üniversitesi, Ankara.

Kanat, S (2008). Görsel sanatlar dersinde çoklu zeka kuramına dayalı öğretim yönteminin 7. sını öğrencilerinin başarısına ve öğrendikleri bilgilerin kalıcılığına etkisi.Malatya ili Fatih İlköğretim okulu (Yayınlanmamış yüksek tisans tezi). İnönü Üniversitesi, Malatya.

Karaahmet, S (2011). İşitme engelliler ilköğretim okullarında görsel sanatlar dersini veren öğretmenlerin öğrencilerle iletişimlerinde empati becerilerinin rolü (Yayınlanmamış yüksek lisans tezi). 19 Mayıs Üniversitesi, Samsun.

Kaya Koçak, S (2010). Illköğretim görsel sanatlar eğitimi dersindeki müze etkinliklerine yönelik, öğrenci, öğretmen ve müze yetkililerinin görüşleri (Yayınlanmamış yüksek lisans tezi). Gazi Üniversitesi, Ankara.

Kaya, Ö. (2006). Illköğretim 3. sınıf görsel sanatlar dersinde drama destekli eğitimin yaratıcı sürece katkıları (Yayınlanmamış yüksek lisans tezi). Gazi Üniversitesi, Ankara.

Kayahan, Z (2010). illköğretim I. kademe 5. sınıf görsel sanatlar eğitimi dersinde hikaye anlatım yönteminin yaratıcılı̆̆a etkileri (Yayınlanmamış yüksek lisans tezi). Gazi Üniversitesi, Ankara.

Keleş, P (2012). İlköğretim görsel sanatlar dersinde dijital kültürün öğrencilerin yaratım sürecine etkileri (Yayınlanmamış yüksek lisans tezi). 19 Mayıs Üniversitesi, Samsun.

Kılıç, A (2013). Illköğretim 7. sınıf görsel sanatlar dersinde afiş çalışması ve uygulama aşamaları (Yayınlanmamış yüksek lisans tezi). Gazi Üniversitesi, Ankara.

Kocaman, Ö (2011). İlköğretim görsel sanatlar dersinde verilen temel tasarım eğitiminin yaratıcılığa katkısının belirlenmesi (Yayınlanmamış yüksek lisans tezi). Mustafa Kemal Üniversitesi, Hatay.

Koç, E (2008). Illköğretim görsel sanatlar (resim-iş) dersi öğretim programlarının değerlendirilmesi (1948- 2007 tarihleri arası) (Yayınlanmamış yüksek lisans tezi). Çanakkale Onsekiz Mart Üniversitesi, Çanakkale.

Koç, H (2011). İlköğretim görsel sanatlar eğitimi dersi öğretmenlerinin materyal kullanımına ilişkin görüşleri (Yayınlanmamış yüksek lisans tezi). Gazi Üniversitesi, Ankara.

Konak, A (2012). İlköğretim 6. sınıf görsel sanatlar eğitimi ders içi etkinliklerinin öğrencilerin demokratik tutumlarına etkisi (Yayınlanmamış doktora tezi). Marmara Üniversitesi, İstanbul.

Kök, A (2010). İlköğretim okulları görsel sanatlar dersinde müze bilinci öğrenme alanına yönelik yaratıcı drama uygulamaları ve öğrenci görüşleri (Yayınlanmamış yüksek lisans tezi). Anadolu Üniversitesi, Eskişehir.

Kuşat Lanpir, C (2010). İlköğretim görsel sanatlar dersinde küçük grup çalışmaları: Bir eylem araştrrması (Yayınlanmamış yüksek lisans tezi). Anadolu Üniversitesi, Eskişehir.

Mamur Yılmaz, E (2014). Görsel sanatlar öğretmen adaylarının ilköğretim okulları öğrencilerine sanatsal düzenleme ilkelerinin öğretimine yönelik öğretim materyali tasarım süreçleri (Yayınlanmamış doktora tezi). Gazi Üniversitesi, Ankara.

Marangoz, N (2008). illköğretim 8.sınıf görsel sanatlar dersinde kullanılan kopyalama yöntemi ve müzikli yöntemin öğrencinin görsel sanatlar dersi başarısına etkisinin karşılaştııılması . (Yayınlanmamış yüksek lisans tezi). Gazi Üniversitesi, Ankara.

Metan, A (2007). illköğretim okullarının birinci kademesinde görevli sınıf öğretmenlerinin müzeleri görsel sanatlar eğitimi dersinde kullanmalarına yönelik görüşleri Ankara ili Çankaya ilçesi örneği (Yayınlanmamış yüksek lisans tezi). Gazi Üniversitesi, Ankara.

Okan Akın, N (2006). İlköğretim görsel sanatlar eğitiminde estetik öğretimi (Yayınlanmamış doktora tezi). Gazi Üniversitesi, Ankara.

Özdemir, Ç (2009). İlköğretim I. kademe görsel sanatlar dersinde üç boyutlu uygulamaların öğrenci yaratıcılığına etkisi (Yayınlanmamış yüksek lisans tezi). Gazi Üniversitesi, Ankara.

Özder, E (2008). illköğretim 6. sınıfta görsel sanatlar dersi ile desteklenen matematik öğretiminin öğrenci tutumları ve başarılarına etkisi (Yayınlanmamış yüksek lisans tezi). Gazi Üniversitesi, Ankara. 
Öztek, N (2014). 6. sınıf görsel sanatlar dersine yönelik öğrencilerin sanatsal gelişimine ilişkin tutumları (Yayınlanmamış yüksek lisans tezi). Marmara Üniversitesi. İstanbul.

Pekdağ, G (2011). Illköğretim görsel sanatlar öğretim programının öğretmen görüşlerine göre değerlendirilmesi (Yayınlanmamış yüksek lisans tezi). Balıkesir Üniversitesi, Balıkesir.

Recep, E (2013). Sınıf öğretmenlerinin ve branş öğretmenlerinin ilköğretim 1. kademe görsel sanatlar dersine etkisinin incelenmesi (Yayınlanmamış yüksek lisans tezi). Gazi Üniversitesi, Ankara.

Sağ, M (2009). İlköğretim görsel sanatlar dersinde eleştiri becerilerinin kazandırılması kilim örneği (Yayınlanmamış doktora tezi). Gazi Üniversitesi, Ankara.

Sarı, H (2011). İlköğretim görsel sanatlar dersi öğretim programının kuramsal yapı ve uygulanabilirlik açısından bir değerlendirmesi (Yayınlanmamış doktora tezi). Gazi Üniversitesi, Ankara.

Sarıhan, K (2010). İlköğretim altıncı sınıf görsel sanatlar eğitiminde işbirlikli öğrenme uygulaması (Yayınlanmamış yüksek lisans tezi). Anadolu Üniversitesi, Eskişehir.

Sarkan Tosun, O (2009). Müze incelemelerinin ilköğretim okullarındaki görsel sanatlar eğitimine katkısı Bolu ili örneği (Yayınlanmamış yüksek lisans tezi). Dokuz Eylül Üniversitesi, İzmir.

Selçuk, E (2010). Illköğretim okulları görsel sanatlar derslerinde geometrik obje destekli uygulama çalışmalarının desen eğitimine etkileri (Yayınlanmamış yüksek lisans tezi). Ondokuz Mayıs Üniversitesi, Samsun.

Susuz, M (2012). Illköğretim ikinci kademe görsel sanatlar dersinde değişik teknik ve araç-gereç kullanımının öğrencilerin yaratıcılıklarına etkisi (Yayınlanmamış yüksek lisans tezi). 19 Mayıs Üniversitesi, Samsun.

Süzen, H (2005). İlköğretim okullarında görevli yöneticilerin ve resim-iş öğretmenlerinin müze ve sanat galerilerinin görsel sanatlar (resim-iş) eğitimi amaçlı kullanılmasına ilişkin görüşleri (Yayınlanmamış yüksek lisans tezi). Gazi Üniversitesi, Ankara.

Tan, Z (2009). illköğretim birinci kademe görsel sanatlar eğitimi müze bilinci öğrenme alanında materyal kullanımının etkisi ve uygulanması (Yayınlanmamış yüksek lisans tezi). Selçuk Üniversitesi, Konya.

Tarı, H (2011). İlköğretim okullarının 1.2.3. sınıflarında uygulanan görsel sanatlar dersinin öğretmen görüşlerine dayalı olarak değerlendirilmesi (Yayınlanmamış yüksek lisans tezi). Marmara Üniversitesi, İstanbul.

Tarlakazan, E (2010). İlköğretim görsel sanatlar dersi 6. sınıf kazanımlarının işbirlikli öğrenme yöntemi etkinlikleri ile gerçekleştirilmesinin öğrenci erişisine etkisi görüşleri (Yayınlanmamış doktora tezi). Gazi Üniversitesi, Ankara.

Tekin, M (2011). İlköğretim 2. kademe (6. sınıf) görsel sanatlar dersinde kopya yönteminin öğrencilerin sanatsal çalışmalarına etkisinin incelenmesi (Yayınlanmamış yüksek lisans tezi). Gazi Üniversitesi, Ankara.

Tezcan, M (2011). Sanat Sosyolojisi, Ankara: Anı Yayıncılık.

Tuncel, Z (2009). Hastane ilköğretim okullarındaki görsel sanatlar eğitiminin niteliği konusunda durum incelemesi Ankara il örneği (Yayınlanmamış yüksek lisans tezi). Gazi Üniversitesi, Ankara.

Türkkan, B (2008). illköğretim görsel sanatlar dersi bağlamında görsel kültür çalışmaları: Bir eylem araştırması (Yayınlanmamış doktora tezi). Anadolu Üniversitesi, Eskişehir.

Türkyılmaz, R (2008). İlköğretim okulları 2. kademe(6,7 ve 8. sınıflar) görsel sanatlar dersinde soyut çalışmaların yeri (Yayınlanmamış yüksek lisans tezi). Gazi Üniversitesi, Ankara.

Tütüncü, S (2006). Illköğretim görsel sanatlar (resim-iş) eğitimi dersi çerçevesinde çocuk resminde yaratıcılık kavramının algılanışına ilişkin bir durum çalışması (Yayınlanmamış yüksek lisans tezi). Dokuz Eylül Üniversitesi, İzmir.

Vurucu, Ö (2010). İlköğretim ikinci kademe öğrencilerinin , görsel sanatlar dersinde işbirlikli (Kubaşık) öğrenmeye yönelik görüşlerinin değerlendirilmesi (Yayınlanmamış yüksek lisans tezi). Fırat Üniversitesi, Elazı̆̆.

Yarımca, Ö (2010). İlköğretim II. kademe görsel sanatlar dersinde disiplinler arası yaklaşıma dayalı uygulamalar (Yayınlanmamı doktora tezi). Selçuk Üniversitesi, Konya.

Yeşilyurt, L (2009). İlköğretim okullarındaki ikinci kademe görsel sanatlar dersi programının işlenişinde karşıllaşılan temel sorunlar (Yayınlanmamış yüksek lisans tezi). Çanakkale Onsekiz Mart Üniversitesi, Çanakkale.

Yılmaz Arıkan, E (2011). İlköğretim okullarında yaratıcı drama yönteminin görsel sanatlar eğitiminde kullanılmasının erişi, tutum ve kalıcılığa etkisi: Meram ilköğretim okulu örneği (Yayınlanmamış doktora tezi). Selçuk Üniversitesi, Konya.

Yılmaz, B (2010). Yaratıcı dramanın görsel sanatlar eğitimine etkisinin ilköğretim 5. sınıf düzeyinde incelenmesi (Yayınlanmamış yüksek lisans tezi). Gazi Üniversitesi, Ankara.

Yiğitel, M (2010). Köy ve kent okullarında öğrenim gören ilköğretim II. kademe öğrencilerinin görsel sanatlar dersine ilişkin tutumlarının karşılaştırılması (Yayınlanmamış yüksek lisans tezi). Gazi Üniversitesi, Ankara.

Yükselgün, Ö (2010). İlköğretim görsel sanatlar dersi öğretim programındaki "görsel sanat kültürü" öğrenme alanının uygulanmasına ilişkin sınıf öğretmenlerinin görüşleri (Yayınlanmamış yüksek lisans tezi). Anadolu Üniversitesi, Eskişehir. 